\title{
O DIREITO INTERNACIONAL NAS CONSTITUIÇÕES BRASILEIRAS: EVOLUÇÃO E DESAFIOS DO TREATY-MAKING POWER
}

\author{
INTERNATIONAL LAW IN THE BRAZILIAN CONSTITUTIONAL TEXTS: EVOLUTION \\ AND CHALLENGES OF THE TREATY-MAKING POWER
}

Paula Wojcikiewicz Almeida ${ }^{1}$

\section{Resumo}

O processo brasileiro de conclusão de tratados foi inicialmente caracterizado por uma competência partilhada, conforme previsto na Constituição belga de 1831, que serviu de modelo para o Brasil e outros países. As disposições do texto constitucional brasileiro de 1988 que regem o poder de concluir tratados contrastam com a lógica das constituições anteriores, baseadas na fórmula franco-belga de divisão de poderes. O texto atual confere uma ampla margem de manobra ao poder executivo, sendo este último capaz de decidir quais tratados podem causar gravames ao patrimônio nacional e, portanto, exigir aprovação legislativa. As regras constitucionais não só determinam a competência dos poderes executivo e legislativo no processo de elaboração de tratados, mas também indicam os procedimentos a serem aplicados para a incorporação do direito internacional no Brasil. O processo de incorporação é marcado por um desequilíbrio entre os poderes executivo e legislativo, típico de um país sob regime presidencial. O poder executivo domina todo o processo de conclusão de atos internacionais, sofrendo pouca interferência do legislador. Se a atuação do poder executivo é discricionária e não arbitrária, esta não é imune às críticas. Requisitos históricos, como a promulgação de tratados, não previstos expressamente no texto constitucional, resultam em uma incerteza jurídica que pode comprometer os compromissos assumidos pelo Brasil na esfera internacional.

Palavras-chave: Processo de Conclusão de Tratados; Incorporação; Brasil; Tratados Internacionais; Constituição Brasileira

\begin{abstract}
The Brazilian treaty-making procedure was initially characterized by shared competence, as provided for in the Belgian Constitution of 1831, which served as a model for Brazil and other countries. The current Brazilian constitutional text dates back from 1988. Its rules governing the power to conclude treaties contrast with the logic of previous constitutions, which were based on the Franco-Belgian formula of division of powers. The current text confers a large margin of maneuver to the executive power, the latter being able to decide which treaties may compromise the budget of the state and, therefore require legislative approval. Constitutional
\end{abstract}

\footnotetext{
${ }^{1}$ Doutora em direito pela Université Paris 1 Panthéon-Sorbonne. Doutora em direito pela Universidade do Estado do Rio de Janeiro (UERJ). Professora adjunta de Direito Internacional e Europeu da FGV Direito Rio. Coordenadora da Cátedra Jean Monnet da União Européia (Programa de Direito da União Européia FGV Direito Rio). Pesquisadora do Centro de Justiça e Sociedade (CJUS) da FGV Direito Rio. Pesquisadora associada do Institut de Recherche en Droit International et Européen de la Sorbonne (IREDIES). Pesquisadora visitante do Max Planck Institute for Comparative Public Law and International Law (2014) e da University of Oxford, Faculty of Law (2014). Pesquisadora do Centre d'études et de recherche en droit international et relations internationales de l'Académie de droit international de La Haye (2010). E-mail: paula.almeida@fgv.br
} 
rules not only determine the competence of executive and legislative powers in the process of treaty-making, but also indicate the procedures to be applied for the incorporation of international law in Brazil. The incorporation process is marked by an imbalance between the executive and legislative powers, typical of a country under a presidential regime. The executive power dominates the whole process with a view to concluding international acts, suffering little interference from the legislature. If the executive's power on the matter is discretionary but not arbitrary, it is not immune from criticism. Historical requirements such as the promulgation of treaties, not provided for in the constitutional text, results in a legal uncertainty which may compromise the commitments undertaken by Brazil in the international arena.

Key-words: Treaty-Making Power; Incorporation; Brazil; International Treaties; Legislative Power; Brazilian Constitution.

\section{INTRODUÇÃO}

Até o final do século XVIII, a conclusão dos tratados foi sempre sujeita à vontade dos monarcas $^{2}$. Essa vontade era absoluta. A validade interna de um tratado não se questionava, pois o soberano sempre poderia impor a sua primazia ${ }^{3}$. A política externa, portanto, era apenas uma questão a ser tratada entre príncipes, excluindo qualquer intervenção dos governados que só puderam se envolver com política externa após a revolução francesa. Com efeito, a Revolução produziu uma mudança substancial no direito constitucional na época, introduzindo a técnica democrática em matéria de conclusão de compromissos internacionais ${ }^{4}$. 0 Parlamento francês começou a desempenhar um papel de liderança na conclusão dos tratados e na condução dos assuntos externos, em conformidade com o que dispõe a primeira Constituição escrita de 1791. Como representante da nação, o corpo legislativo, eleito pelo povo, era competente para ratificar os tratados de paz, de aliança e comércio ${ }^{5}$. A liberdade do rei para decretar e assinar tratados internacionais com potências estrangeiras estava, portanto, sujeita à ratificação pela Assembleia Legislativa ${ }^{6}$. A maioria dos textos constitucionais

\footnotetext{
${ }^{2}$ MEDEIROS (A. P. C.), O Poder Legislativo e os Tratados Internacionais, Instituto dos Advogados do Rio Grande do Sul/L\&PM, Porto Alegre, 1983, p. 24; ARAÚJO (J. H. P.), A processualística dos atos internacionais, Ministério das Relações Exteriores, Rio de Janeiro, 1958, p. 147.

${ }^{3}$ MIRKINE-GUETZÉVITCH (B.), "Droit international et droit constitutionnel”, R.C.A.D.I., 1931-IV, pp. 357358.

${ }^{4}$ VISSCHER (P. de), "Les tendances internationales des constitutions modernes", R.C.A.D.I., 1952-I, p. 535.

${ }^{5}$ Esta fórmula permitiu distinguir os tratados que envolvem a intervenção das Câmaras e aqueles que são concluidos apenas pelo Presidente da República, apesar das várias soluções que prevaleceram ao longo da turbulenta história constitucional francesa do século XIX (MESTRE (A.), "Les traités et le droit interne", R.C.A.D.I., 1931-IV, pp. 240-241).

${ }^{6}$ V. título III, capítulo IV, seção III, artigo 3 da Constituição de 1791.
} 
democráticos deram ao legislador uma participação significativa na conclusão dos atos internacionais ${ }^{7}$.

A evolução constitucional da Europa e a participação do poder legislativo e executivo na conclusão dos tratados internacionais foi marcada pela adoção da Constituição Belga de 1831. Trata-se de um texto constitucional inovador, que privilegiou a participação legislativa. A fórmula franco-belga relativa à celebração de tratados internacionais prevê a existência de dois tipos de tratados: os tratados celebrados diretamente pelo executivo; e os tratados submetidos à uma aprovação prévia das Câmaras, como aqueles relativos ao comércio, às finanças do estado e à legislação em vigor ${ }^{8}$. De acordo com o jurista Paul de Visscher, esta evolução dos compromissos internacionais é um fato constitucional porque na maioria dos Estados as constituições submetem à aprovação parlamentar categorias cada vez mais numerosas de tratados internacionais ${ }^{9}$. Parece, portanto, que a divisão de poderes entre o executivo e o legislativo constitui uma regra bem estabelecida na maioria dos Estados ${ }^{10}$, independentemente do sistema presidencial.

A fórmula franco-belga prescreve a intervenção do Parlamento seja para todos os tratados internacionais, seja para alguns deles considerados particularmente importantes. A França e a Inglaterra aplicam a segunda solução, que provou ser a mais aceita em geral ${ }^{11}$. Com efeito, o artigo 8o da lei constitucional francesa de 1875 consagrava a partilha das competências entre o executivo e o legislativo, associando este último à aprovação de determinados tratados claramente definidos pela Constituição. A exigência de ratificação dos tratados mais importantes foi mantida também no artigo 27 da Constituição de 27 de outubro de 1946, que aumentou o envolvimento do Parlamento no processo de ratificação de tratados, acrescentando outros tratados à lista daqueles submetidos à intervenção legislativa ${ }^{12}$. O papel do poder executivo foi reforçado por ocasião da Constituição francesa de 1958 e foi acompanhado de uma limitação do aval parlamentar para um determinado número de

\footnotetext{
${ }^{7}$ ARAÚJO (J. H. P.), op. cit., p. 148.

${ }^{8}$ V. artigo 68 da Constituição Belga de 7 de fevereiro de 1831.

${ }^{9}$ VISSCHER (P. de), op. cit., p. 535. V. também VISSCHER (P. de), "L'adaptation de la Constitution belge aux réalités internationales", Atos do colóquio de 6 e 7 de maio de 1965, Editions de l'institut de sociologie, Bruxelas, $135 \mathrm{p}$.

${ }^{10}$ ROUSSEAU (C.), Droit international public, Dalloz, 11a ed., Paris, 1987, p. 36.

11 VEDEL (G.) Manuel élémentaire de droit constitutionnel, Librairie Du Recueil Sirey, Paris, p. 527 ; CARREAU (D.) Droit international, Pedone, 9a ed., Paris, 2007, p. 125; DUPUY (P.-M.) Droit international public, Dalloz, 8a ed., Paris, 2006, p. 423;

12 Segundo VEDEL (G.), esta classificação intervém em função do objeto dos tratados, sendo igualmente aplicável aos que modificam as leis internas francesas, op. cit., p. 527.
} 
tratados, sobretudo os mais importantes conforme os textos anteriores ${ }^{13}$. Cabe igualmente ao Presidente determinar quais seriam os tratados particularmente importantes que deverão ser diretamente submetidos à aprovação parlamentar. A mitigação do controle parlamentar ao mínimo possível reflete uma preocupação gaulista considerada como fundamental: o fortalecimento do executivo ${ }^{14}$. Além disso, ela formaliza a existência "de acordos internacionais, não sujeitos à ratificação" (artigo 52,alínea 2) ${ }^{15}$. Trata-se de um desdobramento da prática internacional que impõe a aceleração da entrada em vigor de certos tratados ou então a não submissão de alguns tratados de reduzida importância ao legislativo ${ }^{16}$.

Apesar das revisões constitucionais que ocorreram na história da França, não restam dúvidas de que a linha divisória entre os tratados celebrados somente pelo executivo e aqueles que exigem a intervenção do Parlamento está longe de ser claramente desenhada ${ }^{17}$. Um exemplo disso são as discussões sobre o valor jurídico exato da fórmula relativa aos tratados que comprometem as finanças do estado. Esta observação também é válida para um grande número de países como o Brasil. As primeiras Constituições brasileiras tomaram dois caminhos: a aprovação de certos tratados considerados como sendo os mais importantes, e a generalização dessa regra por meio do consentimento do legislativo para qualquer tratado internacional assinado pelo país.

A fórmula franco-belga percorreu o mundo e, sem dúvida, serviu como modelo para o movimento constitucional em diferentes países no sentido de ampliar os poderes dos parlamentos e aumentar suas prerrogativas na celebração de tratados internacionais ${ }^{18}$, incluindo no Brasil. Tendo em vista tal contexto, o presente artigo pretende analisar historicamente o poder de celebrar tratados ou treaty-making power na ordem jurídica brasileira (I), adentrando nas vicissitudes das regras constitucionais imprecisas para, em seguida, examinar criticamente o papel dos poderes executivo e legislativo, bem como de sua interação na prática do processo de conclusão de tratados internacionais no país (II).

\footnotetext{
${ }^{13}$ Acerca deste ponto, v. CARREAU (D.), op. cit., p. 125.

14 Ibid, p. 123.

15 Segundo DUPUY (P.-M.), a ambição dos constituintes era racionalizar a prática de alguns acordos, "que escapam por razões de comodidade ao peso do procedimento parlamentar" (tradução livre do autor), op. cit., p. 423. Vide CARREAU (D.), op. cit., p. 126.

${ }^{16}$ ARAÚJO (J. H. P.), op. cit., p. 152.

${ }^{17} \operatorname{MESTRE}($ A.), op. cit., p. 240.

18 MIRKINE-GUETZÉVITCH (B.), op. cit., pp. 365-366; ROUSSEAU (C.), op. cit., p. 37.
} 


\section{O TREATY-MAKING POWER NA ORDEM JURÍDICA BRASILEIRA}

Com efeito, as primeiras Constituições brasileiras seguiram o modelo franco-belga de uma competência conjunta entre o executivo e o legislativo (A). À época, foram tomados dois caminhos: a aprovação de certos tratados considerados como sendo os mais importantes, e a generalização dessa regra por meio do consentimento do legislativo para qualquer tratado internacional assinado pelo país. O advento da Constituição de $1988^{19}$ alterou a lógica anterior através da introdução de uma cláusula que abre caminho para a discrição do poder executivo, permitindo-lhe não submeter ao Congresso Nacional os tratados, acordos ou instrumentos internacionais não afetem o patrimônio nacional (B).

\section{A evolução do treaty-making power nas primeiras constituições brasileiras}

A Constituição Política do Império do Brasil de 25 de março de 1824 permaneceu em vigor durante 65 anos, sendo revogada somente em 1889. Esta é a razão pela qual é considerada a segunda Constituição escrita de maior duração depois daquela dos Estados Unidos $^{20}$. Esta Constituição seguiu o modelo franco-belga, segundo a qual a intervenção do poder legislativo é obrigatória para certos tratados considerados particularmente importantes ${ }^{21}$. Trata-se, neste caso, de tratados que dizem respeito à cessão ou troca do território do Império ou de posses que pertencem ao Império e isso apenas em tempos de $\operatorname{paz}^{22}$.

Cabe ao poder executivo a tarefa de concluir os tratados internacionais por razões práticas. José Antonio Pimenta Bueno, jurista que interpretou habilmente a Constituição do Império, argumenta que este papel deveria ser atribuído, pelo menos em teoria, ao poder legislativo, pois este é um ato de soberania e uma expressão do voto nacional, que produz

\footnotetext{
19 Para uma análise do contexto político da Constituição de 1988, v. MEDEIROS (M. A.), "Legitimidade, democracia e accountability no Mercosul", RBCS, vol. 23, n.o 67, junho, 2008, p. 59.

20 NOGUEIRA (O.), Constituições brasileiras, vol. 1 - 1824, Senado Federal, Ministério da Ciência e da Tecnologia, Centro de Estudos Estratégicos, 2001, pp. 13-70.

${ }^{21}$ Para uma análise do contexto político no qual a Constituição de 1824 foi adotada, v. LEAL (A. A.), História Constitucional do Brasil, coleção História Constitucional Brasileira, Senado Federal, Brasília, 2002, pp. 47-138. De acordo como o jurista Aurelino Leal, esta Constituição era simplesmente uma lei decorativa. Era como um edifício construído unicamente por fora para dar uma boa impressão ao público e ao exterior, e para ocultar a bandeira do absolutismo (Ibid, p. 149).

${ }^{22}$ Não haveria razão para que o poder executivo violasse a regra de aprovação legislativa em tempos de paz, in BUENO (J. A. P.), Direito Público Brasileiro e Análise da Constituição do Império, Senado Federal, Brasília, 1978, p. 66. V. artigo 102 referente às atribuições do imperador enquanto chefe do poder executivo, Constituição Política do Império do Brasil, elaborada pelo Conselho de Estado e outorgado pelo Imperador D. Pedro I em 25.03.1824.
} 
direitos e obrigações para o Brasil ${ }^{23}$. No entanto, vários textos constitucionais de monarquias liberais enfraqueceram o poder parlamentar no que diz respeito à celebração de tratados internacionais, permitindo que este último apenas seja informado ${ }^{24}$. O mesmo ocorre com relação ao texto constitucional brasileiro de 1824, que obriga o poder executivo simplesmente a informar o poder legislativo acerca da conclusão dos tratados bem determinados caso o interesse e a segurança do estado o permitirem ${ }^{25}$.

Os diferentes projetos que visavam à elaboração da primeira Constituição Republicana de $1891^{26}$ divergiram no que se refere à exigência de uma aprovação legislativa para todos os $\operatorname{tratados}^{27}$. O projeto selecionado, mas ligeiramente modificado, foi o do jurista Magalhães Castro, que condicionava a conclusão dos tratados pelo Presidente da República à aprovação pelo Congresso Nacional. É assim que o poder de concluir tratados se tornou obrigatoriamente partilhado entre o chefe do poder executivo e o Congresso Nacional, nenhuma exceção à regra sendo permitida (Art. 34 e 48 da Constituição de 1891). Esta exigência é produto da experiência política brasileira que busca evitar a conclusão, pelo chefe do executivo, dos tratados capazes de prejudicar o interesse nacional. Tal situação era comum na época do Império ${ }^{28}$. A fórmula $a d$ referendum, introduzida no primeiro texto constitucional republicano, significa que incumbe definitivamente ao Congresso a celebração de tratados e convenções assinados pelo Presidente $^{29}$. Contudo, poderíamos pensar que a decisão definitiva caberia ao Presidente da

\footnotetext{
${ }^{23}$ V. REALE (M.), Figuras da inteligência brasileira, Siciliano, 2aㅡ ed., 1994, p. 244.

${ }^{24}$ ARAÚJO (J. H. P.), op. cit., p. 148.

25 Ibid, p. 152.

26 Para uma análise do contexto político anterior à adoção da primeira Constituição Republicana de 1891, v. LEAL (A. A.), História Constitucional do Brasil, op. cit., pp. 195-249 e BALEEIRO (A.), Constituições brasileiras, vol. 2 - 1891, Senado Federal, Ministério da Ciência e da Tecnologia, Centro de Estudos Estratégicos, 2001, pp. 13-34. A primeira Constituição Republicana de 1891 foi considerada a mais concisa das constituições republicanas brasileiras (Ibid, p. 34). Para as características que marcaram esta Constituição, v. CAVALCANTI (J. B. U.), Constituição Federal Brasileira (1891), coleção História Constitucional Brasileira, Senado Federal, Brasília, 2002, 416 p.

27 Para uma análise dos diferentes projetos, V. MEDEIROS (A. P. C.), op. cit., pp. 112-117.

${ }^{28}$ MEdeIROS (A. P. C.), O Poder de Celebrar Tratados, Sergio Antonio Fabris, Porto Alegre, 1995, p. 118. O jurista Aurelino Leal havia ressaltado a existência de uma confusão entre os poderes executivo e legislativo, cada um ultrapassando o domínio de competência que lhe era próprio. Acerca deste ponto, v. LEAL (A. A.), História Constitucional do Brasil, op. cit., p. 157.

${ }^{29} \mathrm{O}$ legislador optou pela fórmula ad referendum, que supõe uma permissão prévia do Congresso para que o Presidente possa concluir os atos internacionais. Acerca deste ponto, v. FRANCO (A. A. M.), Estudos de Direito Constitucional, Forense, Rio de Janeiro, 1957, p. 263. De acordo VALLADÃO (H.), ad referendum significa submeter ao Congresso Nacional com o objetivo de que ele delibere, decida ou resolva, o que se diferencia do referendum popular (VALLADAO (H.), "Conceito moderno de ratificação dos tratados e convenções, democrático, originário do Direito Internacional americano", in MEDEIROS (A. P. C.) (Org.), Pareceres dos consultores jurídicos do Itamaraty, vol. VI, 1961-1971, Senado Federal, Brasília, 2008, p. 93).
} 
República, pois este é livre para ratificar tratados internacionais após a sua aprovação pelo poder legislativo brasileiro ${ }^{30}$. Com efeito, não havendo oposição para a celebração de um tratado internacional, a decisão final seria do Chefe de Estado ${ }^{31}$. Caso contrário, a decisão legislativa seria definitiva e vincularia o Presidente da República.

Todas as constituições posteriores ${ }^{32}$, em consonância com a de 1891, mantiveram a participação obrigatória do poder legislativo no treaty making power ${ }^{33}$ e fizeram isto através da fórmula ad referendum. Esta exigência responde aos imperativos da democracia ${ }^{34}$ e pode ser explicada devido ao contexto político mais favorável para a posição assumida pelo poder legislativo. A Constituição Brasileira de 1946 foi redigida pela Comissão de Elaboração do texto constitucional no mesmo ano. Tratava-se de um período no qual o poder legislativo nacional procurava se afirmar em resposta ao autoritarismo vigente após a revolução de 1930. Em 1937, o Senado Federal e a Câmara dos Deputados haviam sido fechados pelo Estado Novo ${ }^{35}$. Foi somente em 1946 que o Parlamento foi reaberto, após ter permanecido por um longo tempo sem qualquer contato com o mundo exterior. Esta é a razão pela qual a Constituição de 1946 foi considerada a mais parlamentar e liberal na história republicana brasileira ${ }^{36}$.

30 Nos comentários acerca da Constituição de 1967, emendada em 1969, FERREIRA FILHO (M. G.) afirmava que o Congresso Nacional possuía a última palavra acerca da conclusão dos tratados internacionais, in Comentários à Constituição Brasileira, Saraiva, 6ạ ed., São Paulo, 1986, p. 247.

${ }^{31}$ V. a este respeito MEDEIROS (A. P. C.), O Poder de Celebrar Tratados, op. cit., p. 118.

32 Para mais detalhes sobre as constituições brasileiras, v. POLETTI (R.), Constituições brasileiras, vol. 3 1934,Senado Federal, Ministério da Ciência e da Tecnologia, Centro de Estudos Estratégicos, 2001, 194 p.; PORTO (W. C.), Constituições brasileiras, vol. 4 - 1937, Senado Federal, Ministério da Ciência e da Tecnologia, Centro de Estudos Estratégicos, 2001, 144 p.; BALEEIRO (A.), SOBRINHO (B. L.), Constituições brasileiras, vol. 5 - 1946, Senado Federal, Ministério da Ciência e da Tecnologia, Centro de Estudos Estratégicos, 2001, 134 p.; CAVALCANTI (T. B.), BRITO (L. N.), BALEEIRO (A.), Constituições brasileiras, vol. 6 - 1967, Senado Federal, Ministério da Ciência e da Tecnologia, Centro de Estudos Estratégicos, 2001, 186 p.; e MEDEIROS (A. B.), O Poder Moderador na República Presidencial, coleção História Constitucional Brasileira, Senado Federal, Brasília, 2004, 178 p.

${ }^{33}$ A primeira ideia de treaty making power remete a VATTEL (E.), Le droit des gens ou principes de la loi naturelle appliqués à la conduite et aux affaires des nations et des souverains, v. 3, The Carnegie Institution, Washington, 1916, p. 160. No entanto, um dos primeiros juristas a empregar esta expressão foi WHEATON (H.), quando afirmou que "o poder de concluir tratados depende da constituição civil de cada Estado" (tradução livre do autor), in Eléments du droit international, A. Durand, Paris, 1848, t. 1, p. 227.

${ }^{34}$ MIRANDA (P.), Comentários à Constituição de 1967, tomo III, Revista dos Tribunais, São Paulo, 1967, p. 326.

35 FERREIRA (M. C.), "Os processos constituintes de 1946 e 1988 e a definição do papel do Congresso Nacional na política externa brasileira", Revista brasileira de política internacional, n.o 53 (2), 2010, p. 24. V. também V. BRAGA (S. S.), "A constituinte de 1946 e a nova ordem econômica e social do pós-segunda guerra mundial”, Revista de Sociologia e Política, Curitiba, n.o 6 e 7, 1996, pp. 8-12.

36 Idem.

Revista de Direito da Cidade, vol. 10, no 1. ISSN 2317-7721 pp. 359-392 
Entretanto, esta Constituição apenas previu uma ampliação dos poderes do Congresso Nacional em matéria de política financeira e de produção legislativa, já que o controle legislativo na celebração dos tratados internacionais não estava na ordem do dia. Com efeito, a quantidade de constituintes a favor de um reforço do papel do Congresso Nacional na política externa foi reduzida devido à falta de interesse de deputados e senadores. Não havia nem mesmo subcomissão de relações exteriores no âmbito da Comissão da Constituição. Incumbia, por conseguinte, à Subcomissão do poder legislativo a proposição, em seu relatório, da redação dos artigos relativos ao poder de celebrar tratados na Constituição Brasileira.

O artigo 66 do texto constitucional de 1946, que estabelece que o Congresso Nacional possui competência exclusiva para resolver definitivamente sobre os tratados e convenções celebrados com os Estados estrangeiros pelo Presidente da República, não foi amplamente discutido. O constituinte Mário Massagão foi o único que propôs uma redação diferente para este artigo com o objetivo de fortalecer o poder legislativo, excluindo a referência ao Presidente da República ${ }^{37}$. Esta emenda foi posteriormente aceita por unanimidade pelos parlamentares, mas não foi introduzida no texto final ${ }^{38}$. Na verdade, observa-se que a Constituição de 1946 optou pelo reforço do papel do Presidente da República na celebração de tratados internacionais e manteve o papel tímido do Congresso Nacional.

A Constituição de 1967, seguida de sua alteração em 1969, introduziu no domínio das competências presidenciais a possibilidade de celebrar atos internacionais em geral, o que difere das constituições anteriores na medida em que aquelas mencionavam apenas os tratados e as convenções internacionais, com exceção do texto constitucional de 1891. A inclusão desta nova categoria acaba por eliminar a contradição da Constituição de $1967^{39}$. Ela reage à tentativa de controlar a tendência de celebrar acordos internacionais pelo executivo sem a participação

37 O artigo estava assim redigido: "resolver definitivamente sobre os tratados e convenções internacionais", Ibid, p. 25.

38 As razões da não inclusão no texto final da Constituição permanecem desconhecidas, pois os documentos da Assembleia Constituinte de 1946 que serviram para a redação da versão final do artigo 66 e que tratam da política externa em geral não foram registrados (Ibid, pp. 25-26).

39 O primeiro texto constitucional de 1967, sem as emendas introduzidas em 1969, foi criticado em função de sua má redação, que prevê, ao mesmo tempo, que o Congresso teria uma competência exclusiva de dispor definitivamente sobre os tratados celebrados pelo Presidente e que este estava autorizado a celebrar tratados, convenções e atos internacionais submetidos ao referendum do poder legislativo. Segundo MELLO (C. D. A.), uma leitura do artigo 47 parece admitir os acordos em forma simplificada, isto apesar das disposições do artigo 83 que mencionam todos os atos internacionais, inclusive os tratados, in Curso de Direito Internacional Publico, vol. 1, 15a ed., Renovar, Rio de Janeiro, 2004, p. 237. 
do Congresso Nacional ${ }^{40}$. Este último seria competente, nos termos do artigo 44 da emenda de 1969, para decidir definitivamente sobre os tratados, convenções e atos internacionais celebrados pelo Presidente da República. Poderíamos pensar que a emenda de 1969 eliminou teoricamente a possibilidade de celebrar acordos executivos ${ }^{41}$. Além disso, o emprego da fórmula "atos internacionais" confere uma alta imprecisão ao texto constitucional, que corre o risco de bloquear a política externa ${ }^{42}$. Esta é a razão pela qual esta expressão foi interpretada como um sinônimo de tratado ou convenção.

Contudo, o que caracteriza os textos constitucionais posteriores ao de 1891 é a distinção entre a competência privativa e a competência exclusiva ${ }^{43}$. A Constituição de 1891 empregava indistintamente a fórmula da competência própria, aplicável tanto para o poder executivo quanto para o poder legislativo. Entretanto, isso não foi o caso durante as revisões constitucionais de 1934 e 1946, que introduziram a regra de competência exclusiva em relação às atribuições do Congresso Nacional. Doravante, incumbe exclusivamente ao Congresso Nacional celebrar tratados internacionais. Poderíamos nos perguntar se há uma real diferença entre essas duas noções para que o constituinte tenha escolhido a competência exclusiva. Por um lado, a competência exclusiva de um poder dispensa a colaboração de outro. Por outro lado, a competência própria permite a participação de outro poder. Como resultado, pode-se dizer que a competência do Presidente é privativa, pois depende da aprovação do Congresso Nacional, esta última sendo, ao contrário, exclusiva ${ }^{44}$. A diferença também poderia referir-se à possibilidade de delegação: a competência exclusiva sendo excluída de qualquer delegação, pois os atos que dela decorrem apenas podem ser cumpridos por seu único titular, contrariando a lógica prevalecente para a competência privativa ${ }^{45}$. Quando um órgão dispõe de uma competência privativa, isso não impede que ela seja delegada ${ }^{46}$.

\footnotetext{
${ }^{40}$ FERREIRA FILHO (M. G.), op. cit., p. 373.

${ }^{41} \operatorname{MELLO}($ C. D. A.), op. cit., p. 237.

42 Idem.

${ }^{43} \mathrm{~V}$. acerca deste ponto MEDEIROS (A. P. C.), op. cit., p. 288.

${ }^{44}$ V. FRANCO (A. A. M.), Estudos de Direito Constitucional, Forense, Rio de Janeiro, 1957, p. 262.

45 SILVA (J. A.), Curso de direito constitucional positivo, Malheiros, 25a ed., São Paulo, 2005, p. 480, nota 5. A existência de uma diferença entre a competência exclusiva e a competência privativa é confirmada pelo artigo 84 do texto constitucional que prevê em seu parágrafo único a possibilidade de delegação de certas atribuições do Presidente aos Ministros de Estado, ao Procurador Geral da República ou ao Advogado Geral da União. V. art. 84, § único.

46 Ibid, p. 481.
} 
Além da distinção entre as competências atribuídas a cada poder, as constituições posteriores a de 1891 eliminaram a palavra "sempre", que condicionaria obrigatoriamente a celebração de acordos, convenções e tratados à aprovação do Congresso ${ }^{47}$.

\section{A fórmula imprecisa prevista na Constituição Federal de 1988}

O artigo 84, VIII, primeira parte da Constituição brasileira de 1988, determina que compete "privativamente" ao Presidente da República celebrar tratados, convenções e atos internacionais, bem como manter relações com Estados estrangeiros. Classicamente, a negociação de tratados internacionais é de responsabilidade do Presidente da República, dotado de uma competência privativa para negociá-los e ratificá-los. Não obstante, a doutrina brasileira segue a prática internacional ao admitir que o presidente possa designar outros representantes capazes de obrigar o Estado internacionalmente ${ }^{48}$. A concessão de poderes para negociar e celebrar tratados no Brasil é regulamentada pelo Decreto n. ${ }^{\circ} 5979-6$ de 06 de dezembro de 2006, que aprova a estrutura regulamentar e o quadro demonstrativo das posições em comissão e das funções atribuídas ao Ministério das Relações Exteriores. Por consequência, cabe a este último, como órgão auxiliar do Presidente da República, a competência para estabelecer negociações diplomáticas que resultarão em acordos internacionais ${ }^{49}$.

Resta saber se os acordos negociados pelo poder executivo devem ser submetidos à aprovação do poder legislativo brasileiro, conforme o texto da Constituição de 1988. Este texto modificou as regras relativas à conclusão dos tratados internacionais previstas nas constituições anteriores, introduzindo um elemento distintivo para aqueles que deverão ser obrigatoriamente submetidos ao Congresso Nacional. Uma leitura do artigo que trata da organização do poder de celebrar tratados da Constituição Brasileira de 1988 (Art. 84, VIII) poderia levar a crer que todos os tratados internacionais assinados pelo Presidente da República devem ser submetidos à aprovação do Congresso Nacional, em conformidade com a redação da primeira Constituição Republicana de 1891.

\footnotetext{
${ }^{47}$ MEDEIROS (A. P. C.), op. cit., p. 289.

${ }^{48}$ A hipótese de delegação dos poderes para plenipotenciários encontra-se no artigo 7,\$2, da Convenção de Viena sobre o direito dos tratados. Ver também DAILLER, P. PELLET, A. Droit International Public, L.G.D.J., 7ạ ed., Paris, 2002, p. 127; Mello, C. A. Curso de Direito Internacional Público, Saraiva, vol. 1, 11a ed., São Paulo, p. 195.

${ }^{49}$ As competências do Ministério de Relações Exteriores encontram-se nos artigos 27 da lei n.o 10.683 de

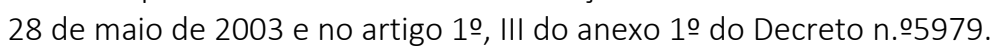


Um exame cuidadoso do Art. 84, VIII e de sua aplicação demonstra, contudo, que a tese de uma ampliação dos poderes do Congresso Nacional pelo texto constitucional de 1988 não poderia ser convincente ${ }^{50}$. Com efeito, uma análise conjunta do artigo 49, I é necessária para se compreender o verdadeiro alcance desta disposição. Este artigo serve para distinguir os tratados que exigem a aprovação do Congresso Nacional daqueles que estão dispensados desta exigência. Determina que é da competência exclusiva do Congresso "resolver"1 definitivamente sobre tratados, acordos ou atos internacionais que acarretem encargos ou compromissos gravosos ao patrimônio nacional". Estas são as únicas disposições do texto constitucional atual relativas à celebração e à inserção de tratados internacionais no ordenamento jurídico brasileiro ${ }^{52}$.

$\mathrm{Na}$ ausência de outras disposições constitucionais que regulem a incorporação de atos unilaterais adotados por organizações internacionais ${ }^{53}$, usa-se a mesma fórmula prescrita nos artigos 49, I e 84, VIII para proceder à sua incorporação. Isso porque, a menção referente aos "atos internacionais" também incluiria aqueles adotados em virtude de uma organização internacional, como o Mercosul ${ }^{54}$. De fato, a aplicabilidade das soluções do direito internacional clássico à incorporação do direito de organizações internacionais como o Mercosul foi reiteradamente confirmada pelo Supremo Tribunal Federal brasileiro ${ }^{55}$.

As disposições da Constituição de 1988 respondem a uma tendência do direito constitucional moderno de atenuar a obrigação geral de submissão de tratados e convenções internacionais ao poder legislativo em razão do progresso das relações internacionais, do aumento do número de acordos internacionais e de sua urgência, bem como da celebração de

\footnotetext{
${ }^{50}$ Acerca deste ponto, v Mello C. A., op. cit. p. 237.

${ }^{51}$ V. VALLADÃO, H. "Conceito moderno de ratificação dos tratados e convenções, democrático, originário do Direito Internacional americano", in MEDEIROS (A. P. C.) (Org.), Pareceres dos consultores jurídicos do Itamaraty, vol. VI, 1961-1971, Senado Federal, Brasília, 2008, p. 88.

52 Wojcikiewicz Almeida, P., Pereira, M. F. L., "Revisitando os efeitos da assinatura de um tratado internacional: da obrigação de boa-fé à sujeição internacional do Estado", Revista DIREITO GV, v. 9, n. 1, jan-jun 2013.

53 DAILLER, P. FORTEAU, M., PELLET, A. Droit International Public, LGDJ, 8a ed., Paris, 2009, p. 404, ver também VIRALLY, M. "Unilateral acts of international organizations", in Bedjaoui, M. (Org.), International law: achievements and prospects, ed. Martinus Nijhoff, Dordrecht, 1991, pp. 241-263.

${ }^{54}$ Neste sentido, v. CANÇADO TRINDADE, A. A. Repertório da prática diplomática brasileira do Direito Internacional Público, 1889-1898, Fundação Alexandre de Gusmão, Brasília, 2012, p. 94.

${ }^{55}$ Em um acórdão emblemático, que originou uma jurisprudência que se tornou constante, o STF afirmou que a recepção de tratados e atos celebrados pelo Brasil no Mercosul está sujeita às mesmas regras constitucionais que regem o procedimento de incorporação de tratados e atos internacionais no ordenamento jurídico brasileiro (STF) Agravo regimental em carta rogatória n.․ 8.279-4, relator Ministro Celso de Mello, jugado em 17 de junho de 1998.
} 
alguns tratados considerados de menor importância ${ }^{56}$. A presente constituição admite, portanto, a conclusão de atos internacionais unicamente pelo presidente ${ }^{57}$, reforçando o poder conferido ao executivo em detrimento de um parecer obrigatório do legislativo. Efetivamente, compete ao executivo determinar, dentre os tratados particularmente importantes, aqueles que devem ser diretamente submetidos à aprovação legislativa. A análise recairá sobre o fato de os acordos em questão serem capazes produzir encargos ou compromissos gravosos ao patrimônio do Estado. Para tanto, uma ampla interpretação é necessária: não se trata somente de encargos ou compromissos de natureza financeira, mas também aqueles de natureza política.

Os dispositivos constitucionais relativos à celebração de tratados, acordos e atos internacionais sofreram críticas relacionadas à sua imprecisão, ambiguidade e inadequação ${ }^{58}$. É importante compreender que a escolha dos constituintes brasileiros não foi feita de forma aleatória. As razões políticas que atribuem, por meio da Constituição de 1988, um papel menos ativo ao Congresso Nacional se encontram no processo de elaboração do texto constitucional ${ }^{59}$. A escolha dos constituintes brasileiros também foi guiada por imperativos jurídicos destinados a garantir uma participação legislativa obrigatória relativa aos acordos celebrados com o F.M. ${ }^{60}$.

Verifica-se que a Constituição de 1988 perdeu a oportunidade de esclarecer as regras relativas à conclusão de tratados internacionais e manteve a dualidade doutrinária: alguns autores sustentam que todos os tratados devem ser obrigatoriamente submetidos ao poder legislativo e outros consideram a possibilidade de celebração dos acordos executivos ${ }^{61}$. A

\footnotetext{
56 PEREIRA DE ARAUJO, J. H. A processualística dos Atos Internacionais, Ministério de Relações Exteriores, Rio de Janeiro, 1958, p. 149.

${ }^{57}$ V. BASTOS C. R. Comentários à Constituição do Brasil, Saraiva, 3ạ ed., vol. 4, t.1, São Paulo, 2002, p. 112. ${ }^{58}$ Ferreira Filho M. G. Comentários à Constituição Brasileira de 1988, vol. II, Saraiva, São Paulo, 1992, p. 21; CÂMARA J. S. "A conclusão dos tratados internacionais e o direito constitucional brasileiro", Boletim da Sociedade Brasileira de Direito Internacional, Brasília, 69/71:74, 1987-1989; Albuquerque Mello, C. Curso de Direito Internacional Público, Renovar, 15a ed., 2004, p. 277.

59 FERREIRA, M. C. "Os processos constituintes de 1946 e 1988 e a definição do papel do Congresso Nacional na política externa brasileira", Revista brasileira de política internacional, n.o 53 (2), 2010, p. 32 34, 39-41; MARTINEZ-LARA, J. Building Democracy in Brazil: Politics of Constitutional Change, 1985-1995, St. Martin's Press, New York, 1996, p. 108; LAMOUNIER B. "A feitura da nova constituição: um reexame da cultura política brasileira" in Lamounier B. (Org.), De Geisel a Collor: o balanço da transição, ed. Sumaré, São Paulo, 1990, p. 82.

${ }^{60}$ O legislador possuía, sem dúvida, a intenção de limitar a margem de manobra do poder executivo por meio da submissão obrigatória dos acordos celebrados no domínio financeiro ao Congresso. Todavia, foi o efeito contrário que ocorreu, pois o poder executivo se beneficiou amplamente da autoridade constitucional. Nesse sentido, vide Medeiros, A. P. C. O poder de celebrar tratados, Sergio Antonio Fabris, Porto Alegre, 1995, p. 385 e Câmara J. S., op. cit., p. 73.

${ }^{61}$ MEDEIROS, A. P. C., op. cit., p. 383.
} 
segunda tendência, que permite a celebração de certos acordos sem intervenção legislativa, concretizou-se na prática diplomática brasileira (executive agreements).

As práticas constitucionais são claramente influenciadas pela posição de princípio no que se refere à relação entre direito internacional e direito interno prevista pelas constituições nacionais ${ }^{62}$. Isto leva a pensar que os Estados que aderiram à concepção dualista, com a infinidade de variações que dela decorrem, não tendem a facilitar, do ponto de vista técnico, a aplicação imediata do direito internacional ${ }^{63}$.

\section{O PAPEL DOS PODERES EXECUTIVO E LEGISLATIVO NO TREATY-MAKING POWER}

As práticas constitucionais são, com efeito, claramente influenciadas pela posição de princípio no que se refere à relação entre direito internacional e direito interno prevista pelas constituições nacionais ${ }^{64}$. Isto leva a pensar que os Estados que aderiram à concepção dualista, com a infinidade de variações que dela decorrem, não tendem a facilitar, do ponto de vista técnico, a aplicação imediata do direito internacional ${ }^{65}$.

Tendo aderido à doutrina dualista moderada, a formação do direito internacional no Brasil baseia-se no Estado, o único com competência para adotar um ato de vontade que torna aplicável uma norma internacional no ordenamento jurídico interno ${ }^{66}$. O Estado determinará, portanto, consoante a natureza e o grau de importância das medidas necessárias, se a incorporação será feita por conta do poder executivo, que detém um domínio quase completo e desmedido do processo de incorporação (A) ou, então, pelos cuidados do poder legislativo de forma conjunta, cuja intervenção está amplamente enquadrada e condicionada pela ação do poder executivo (B).

\footnotetext{
62 MOSLER, H., "L’application du droit international public par les tribunaux nationaux", R.C.A.D.I., 1957-I, n. 091, p. 636 .

${ }^{63} \mathrm{Ibid}, \mathrm{p} .637$.

${ }^{64}$ MOSLER (H.), op. cit., p. 636.

$65 \mathrm{lbid}, \mathrm{p} .637$.

66 TRIEPEL (H.), op. cit., p. 84. Trata-se de uma "discussão de escola", já que a prática não confirma absolutamente nenhuma das duas teses. Neste sentido v. ROUSSEAU (C.), op. cit., p. 15. Para as relações entre direito interno e direito internacional e a oposição entre as duas doutrinas v., por exemplo, VIRALLY (M.), "Sur un pont-aux-ânes: les rapports entre droit international et droits internes", Mélanges H. Rolin, Paris, Pedone, 1964, p. 488 e seguintes; ROUSSEAU (C.), Droit international public, op. cit., pp. 4-15; e DUPUY (J.-M.), op. cit., pp. 417-419. Para o monismo, v. KELSEN (H.), "Les rapports de système entre le droit interne et le droit international public", R.C.A.D.I., 1926-IV, pp. 227-331; e SCELLE (G.), "Règles générales du droit de la paix", R.C.A.D.I., 1933, t. 46, pp. 327-703. Para o dualismo, v. TRIEPEL (H.), "Les rapports entre le droit interne et le droit international", R.C.A.D.I., 1923-I, pp. 77-118.
} 


\section{A ampla atuação do poder executivo}

A fim de avaliar a extensão do poder executivo no momento anterior à submissão ao legislativo das normas internacionais, uma compreensão aprofundada do procedimento em vigor se impõe. Esta passagem se faz essencial para que se possa apreender o poder quase ilimitado de que dispõem as autoridades executivas, ao decidir se um ato internacional será submetido ao Congresso Nacional. Esta margem de manobra é fonte de críticas pelo poder legislativo, pondo em causa a adequação de tal procedimento para a celebração dos atos internacionais.

O processo de incorporação tem início a partir de uma ação do poder executivo brasileiro, considerado o chefe da política internacional. Incumbe ao Ministro das Relações Exteriores submeter a norma à apreciação do Presidente da República através de um projeto de mensagem ao Congresso Nacional, acompanhado de uma exposição de motivos. Sabe-se que os ministros desfrutam de uma presunção de representatividade e não devem apresentar carta de plenos poderes durante a celebração de tratados internacionais ${ }^{67}$. Eles são assistidos pelo Secretariado Geral das Relações Exteriores ${ }^{68}$. Este é composto, entre outros órgãos, de uma Subsecretaria-Geral do Serviço Exterior, incluindo uma Divisão de Atos Internacionais (“D.A.I.") ${ }^{69}$. Esta divisão, que faz parte do Departamento de Assuntos Consulares, Jurídicos e de Assistência aos brasileiros no exterior, é o órgão do executivo detentor da principal responsabilidade no que diz respeito à celebração de tratados e atos internacionais em geral ${ }^{70}$. Cabe à D.A.I. elaborar a exposição de motivos, assinada pelo Ministro das Relações Exteriores e enviada à Presidência da República.

Antes de enviar a exposição de motivos, a D.A.I. transmite o tratado ao organismo responsável pela consultoria jurídica do Ministério, estabelecido pelo Decreto n.o 2358, de 19 de fevereiro de 1859. Seu papel é auxiliar os ministros por meio da elaboração de um parecer jurídico sobre os atos internacionais assinados pelos representantes do Estado ${ }^{71}$. Em razão do aviso n.o 1872/99, do Ministro Chefe da Casa Civil da Presidência da República, a apreciação da

\footnotetext{
67 Para mais detalhes sobre o poder de celebrar tratados internacionais, v. Repertório da prática diplomática brasileira do Direito Internacional Público, 1899-1918, ed. Fundação Alexandre de Gusmão, Brasília, 2012, p. 136.

${ }^{68}$ Art. 8 do anexo 1으 do decreto n. 0 5979, de 6 de dezembro de 2006.

69 V. art. 129 do Regulamento Interno da Secretaria de Estado de Relações Exteriores, aprovado pelo acórdão n.o 212 de 30 de abril de 2008 do Ministério de Relações Exteriores.

70 V. Regulamento Interno da Secretaria de Estado de Relações Exteriores.

${ }^{71}$ As competências da consultoria jurídica estão enumeradas no art. 7 do anexo 1ㅇ do decreto n. 5979, de 6 de dezembro de 2006.
} 
D.A.I. é indispensável para qualquer ato internacional ou regional que obrigue o país a partir de 27 de outubro de 1999. Com efeito, a Casa Civil da Presidência da República se compromete a não dar seguimento aos acordos que não estiverem acompanhados de um parecer do conselheiro jurídico sobre a constitucionalidade, a técnica jurídica e a boa técnica legislativa do instrumento em questão. O parecer do consultor jurídico, bem como aqueles eventualmente elaborados por outros órgãos de assistência jurídica, serão anexados à exposição de motivos devidamente assinada pelo Ministro de Relações Exteriores ${ }^{72}$. Todos os ministérios competentes na matéria abordada pelo tratado devem se pronunciar, assinando em conjunto a exposição de motivos $^{73}$.

O texto do tratado ou da norma, bem como seus anexos devem ser traduzidos. As reservas feitas pelo poder executivo devem ser identificadas expressamente ${ }^{74}$. Por meio da exposição de motivos, o ministro explica as razões pelas quais o ato internacional foi assinado e pede ao Presidente para submetê-lo ao Congresso Nacional através de uma mensagem. Tão logo o Presidente aprove a exposição dos motivos, o tratado será transformado em mensagem do executivo e encaminhado ao Congresso Nacional, particularmente ao Secretário-Geral da Mesa da Câmara dos Deputados ${ }^{75}$.

Note-se neste ponto que a decisão de enviar o ato internacional ao Congresso Nacional permanece nas mãos do poder executivo. Durante esta análise jurídica preliminar, o poder executivo determinará se o ato internacional entra na categoria dos acordos executivos, podendo ser concluído unicamente pelo executivo, ou se este deve ser submetido ao Congresso Nacional, em conformidade com as disposições constitucionais que regem a conclusão dos

72 Para uma análise dos pareceres consultivos que instituem a exigência de aprovação legislativa prévia para a ratificação e promulgação de atos internacionais, v. CANÇADO TRINDADE (A. A.), Repertório da prática diplomática brasileira do Direito Internacional Público, 1889-1898, ed. Fundação Alexandre de Gusmão, Brasília, 2012, p. 81; CANÇADO TRINDADE (A. A.), Repertório da prática diplomática brasileira do Direito Internacional Público, 1899-1918, ed. Fundação Alexandre de Gusmão, Brasília, 2012, pp. 125-127; CANÇADO TRINDADE (A. A.), Repertório da prática diplomática brasileira do Direito Internacional Público, 1899-1918, ed. Fundação Alexandre de Gusmão, Brasília, 2012, p. 147-168; CANÇADO TRINDADE (A. A.), Repertório da prática diplomática brasileira do Direito Internacional Público, 1919-1940, ed. Fundação Alexandre de Gusmão, Brasília, 2012, pp. 113-119; CANÇADO TRINDADE (A. A.), Repertório da prática diplomática brasileira do Direito Internacional Público, 1941-1960, ed. Fundação Alexandre de Gusmão, Brasília, 2012, pp. 92-101; CANÇADO TRINDADE (A. A.), Repertório da prática diplomática brasileira do Direito Internacional Público, 1961-1981, ed. Fundação Alexandre de Gusmão, Brasília, 2012, p. 155 e 163.

${ }^{73}$ Artigo 37, § 2 do decreto n.o 4176, de 28 de março de 2002, que estabelece as normas e diretrizes para a elaboração, redação, edição e envio de projetos de consolidação de atos normativos de competência dos órgãos do poder executivo federal para o Presidente da República.

${ }^{74} \mathrm{O}$ artigo 38 do decreto n.o 4176, de 28 de março de 2002, estabelece o conteúdo da exposição dos motivos.

${ }^{75}$ Para mais detalhes, v. artigo 14 e seguintes do R.I.C.D. 
tratados internacionais no Brasil. Tal decisão não é sem critérios. Para fazer isso, o órgão competente avaliará o conteúdo e a natureza do ato internacional a ser incorporado a fim de verificar se este pode trazer encargos ao patrimônio nacional ou se este se insere no domínio da lei. Em todo caso, o poder executivo não é obrigado a dar prosseguimento ao processo de incorporação através do envio do tratado ao Congresso Nacional. Com exceção das convenções internacionais sobre o direito do trabalho, o Chefe de Estado é livre para arquivar todos os outros atos internacionais ou regionais caso ele o considere conveniente ${ }^{76}$. Apesar das tentativas de transformar a submissão ao poder legislativo como regra obrigatória, trata-se sempre de uma escolha discricionária do Presidente da República e não de uma decisão arbitrária ${ }^{77}$.

Não é incomum que um tratado ou ato internacional demore para ser enviado ao Congresso Nacional. A incorporação da Convenção de Viena sobre o Direito dos Tratados de 1969 no sistema jurídico brasileiro ilustra este problema. Este exemplo é usado frequentemente por membros do poder legislativo brasileiro para mostrar que um ato internacional continua dependendo da boa vontade do poder executivo para que possa prosseguir com o processo de incorporação através do envio do ato em questão ao Congresso Nacional ${ }^{78}$.

${ }^{76}$ A Constituição da Organização Internacional do Trabalho (O.I.T.) prevê uma particularidade sem precedentes no direito internacional. Trata-se da obrigação dos Estados Membros de submeter à sua autoridade competente, no prazo de um ano a partir do encerramento da sessão, as convenções adotadas pela Conferência Internacional do Trabalho, a fim de transformá-las em lei (artigo 19, §5, alínea b) da Constituição da O.I.T.). Os Estados Membros também devem informar o Diretor-Geral do Bureau International du Travail (B.I.T.) sobre as medidas tomadas para submeter a convenção à autoridade competente, e sobre as medidas adotadas por este último (artigo 19, §5, alínea c). 0 artigo 19, §5, alínea e), da Constituição afirma que se uma convenção não obtém o consentimento da autoridade ou autoridades, o Membro não será submetido a qualquer obrigação, exceto que deverá elaborar relatórios ao Diretor-Geral. Trata-se de uma obrigação acessória imposta aos Estados Membros que não ratificaram uma ou mais convenções da O.I.T. Para mais detalhes sobre as convenções da O.I.T., V. MAHAIM (E.), "L'organisation permanente du travail", R.C.A.D.I., 1924, III, vol. 4, pp. 65-223; MAUPAIN (F.), "L'OIT, la justice sociale et la mondialisation", R.C.A.D.I., 1999, vol. 278, pp. 201-396; WOLF (F.), "L'interdépendance des Conventions internationales au travail", R.C.A.D.I., 1967, II, vol. 121, pp. 113-219.

${ }^{77}$ Uma das propostas de redação do artigo 18 da Convenção de Viena sobre o Direito dos Tratados de 1969 incluía o envio do texto convencional aos poderes constitucionais competentes a fim de obrigar o Estado contratante em vista de sua aprovação ou rejeição. Lauterpacht, relator especial da Comissão de Direito Internacional das Nações Unidas nos anos 1953 e 1954, considerou que tal redação poderia motivar a ratificação do tratado pelo Estado em caso de sua aprovação pelo poder legislativo. Para o jurista, a obrigação de submeter o tratado, após a sua assinatura, às autoridades competentes do Estado deveria ser uma exigência que decorre da boa-fé. A proposta de Lauterpacht reflete uma expectativa legítima e coerente, que resulta da manifestação da vontade expressa pelo Estado no momento da assinatura (Organização das Nações Unidas, Comissão de Direito Internacional, Anuário da Comissão de Direito Internacional, vol. II, LAUTERPACHT (H.), Droit des traités, document A/CN.4/63, 1953, p. 108).

${ }^{78}$ A Convenção foi assinada pelo país em maio de 1969. De acordo com o processo constitucional, o texto da Convenção deveria ser submetido ao Congresso Nacional para aprovação, pois produzia 
Após a aprovação legislativa, o ato internacional deverá ser promulgado. Assim como para a adoção de leis internas, a promulgação é o ato pelo qual o Presidente da República constata o respeito do procedimento previsto pela Constituição, verifica o texto do instrumento adotado e dá-Ihe sua autenticidade, tornando-o executável ${ }^{79}$. O decreto de promulgação é usado para garantir que o conteúdo da regra estatal corresponda ao conteúdo da regra jurídica internacional que ele visa incorporar; e também para confirmar a conformidade do procedimento legislativo ${ }^{80}$. No entanto, o executivo permanece dotado de uma margem de manobra significativa, pois não há nada que permita assegurar que a promulgação ocorrerá. Trata-se de uma exigência que não encontra base jurídica no texto constitucional, sendo um resultado da prática diplomática brasileira, datada da época do Império.

No Brasil, a promulgação pelo Presidente dos atos internacionais que tenham sido previamente aprovados pelo poder legislativo é um procedimento obrigatório para lhes dar pleno efeito no direito interno ${ }^{81}$. Não se trata de uma obrigação constitucional, mas convencional do Estado ${ }^{82}$. Apesar do silêncio do texto constitucional de 1824 e das constituições subsequentes, a promulgação é um reflexo da prática diplomática brasileira de

compromissos gravosos ao patrimônio nacional. O poder executivo tardou, no entanto, a submetê-lo ao legislativo. Esta Convenção permaneceu por 23 anos no âmbito do executivo. Este último só a submeteu ao Congresso em 1992, através da mensagem n.o 116/1992 do Presidente da República. Assim, o Congresso a recebeu em 18 de maio de 1992. Neste caso em particular, o executivo não foi o único responsável pela demora na adoção dos procedimentos internos necessários. O texto da Convenção permaneceu outros 17 anos perante as Comissões e o órgão plenário da Câmara dos Deputados. Foi apenas em 14 de maio de 2009 que a Convenção foi aprovada pela Câmara e depois pelo Senado em junho do mesmo ano. Nos dois meses seguintes, o projeto de decreto foi convertido no decreto legislativo n.o 496/2009, devidamente publicado no Diário Oficial da União em 20 de julho de 2009, e no da Câmara dos Deputados em 18 de julho de 2009. A Convenção foi ratificada em 25 de setembro de 2009, obrigando o país na esfera internacional. A entrada em vigor na ordem jurídica nacional ocorreu com a publicação do decreto de promulgação em 15 de dezembro de 2009.

${ }^{79}$ A este respeito, v. DEBBASCH (C.), PONTIER (J.-M.), BOURDON (J.), RICCI (J.-C.), Droit constitutionnel et institutions politiques, Economica, 4a ed., Paris, 2001, p. 736; ACCIOLY (H.), "A ratificação e a promulgação dos tratados...", op. cit., p. 10; et MESTRE (A.), op. cit., p. 256. Segundo MALBERG (R. C.), a promulgação "tem uma destinação tripla: inicialmente ela representa uma constatação da adoção da lei pelo órgão legislativo; ela é a certificação da existência da lei e de seu texto; enfim, ela é a afirmação de seu valor imperativo e executório" (tradução livre do autor), in Contribution à la théorie générale de I'État, Sirey, Paris, 1920, C.N.R.S., 1962. V. também RODAS (J. G.), A publicidade dos tratados internacionais, Revista dos Tribunais, São Paulo, 1980, p. 200.

80 TRIEPEL (H.), op. cit., p. 97. V. também MELLO (C. D. A.), Curso de Direito Internacional Público, Renovar, 15a ed., vol. 1, Rio de Janeiro, 2004, p. 240.

81 PEREIRA DE ARAUJO (J. H.), A processualística dos atos internacionais, Ministério de Relações Exteriores, Rio de Janeiro, 1958, p. 243.

$82 \operatorname{MESTRE}($ A.), op. cit., p. 256. 
incorporação de tratados, empregada desde o Império ${ }^{83}$. Sua adoção no Brasil foi baseada num uso frequente em Portugal ${ }^{84}$, mesmo que não fosse mais utilizada pelas Constituições da França, de Luxemburgo e dos Países Baixos ${ }^{85}$. Na França, por exemplo, a promulgação foi exigida até a adoção da Constituição de $1946^{86}$. Atualmente, é suficiente que o tratado seja ratificado e publicado a fim de tornar-se obrigatório na ordem interna, sendo que nenhuma referência é feita à promulgação no presente texto constitucional francês ${ }^{87}$.

Os atos internacionais que requerem incorporação serão promulgados após a sua aprovação pelo Congresso Nacional, através de um decreto assinado pelo Presidente da República e aprovado pelo M.R.E. ${ }^{88}$. Com efeito, incumbe ao Presidente da República, nos termos do texto constitucional, sancionar, promulgar e publicar leis, bem como editar os respectivos decretos para sua execução ${ }^{89}$. A edição do decreto de promulgação ocorre somente após o parecer do conselheiro jurídico do M.R.E., que deve confirmar a inexistência de obstáculos jurídicos que sirvam de impedimento à promulgação do ato internacional ou regional. No entanto, é importante ressaltar que não há qualquer prazo para que o Chefe de Estado promulgue os tratados ${ }^{90}$. Portanto, a entrada em vigor interna se conclui com a

${ }^{83} \mathrm{O}$ Tratado de reconhecimento da independência e do império entre o Brasil e Portugal, assinado em 29 de agosto de 1825, foi promulgado pelo Decreto de 10 de abril de 1826, após a troca dos instrumentos de ratificação, in MEDEIROS (A. P. C.), op. cit., p. 470. O texto deste primeiro decreto de promulgação pode ser consultado na obra de PEREIRA DE ARAUJO (J. H.), op. cit., pp. 251-252. Para mais detalhes referentes ao sistema de promulgação e sua adoção pelo Brasil, v. PEREIRA DE ARAUJO (J. H.), op. cit., pp. 249-250. Acerca da exigência de uma promulgação dos atos internacionais para sua entrada em vigor no quadro interno, v. CANÇADO TRINDADE (A. A.), Repertório da prática diplomática brasileira do Direito Internacional Público, 1889-1898, ed. Fundação Alexandre de Gusmão, Brasília, 2012, p. 81; CANÇADO TRINDADE (A. A.), Repertório da prática diplomática brasileira do Direito Internacional Público, 18991918, ed. Fundação Alexandre de Gusmão, Brasília, 2012, pp. 125-127; CANÇADO TRINDADE (A. A.), Repertório da prática diplomática brasileira do Direito Internacional Público, 1899-1918, ed. Fundação Alexandre de Gusmão, Brasília, 2012, p. 147-168; CANÇADO TRINDADE (A. A.), Repertório da prática diplomática brasileira do Direito Internacional Público, 1919-1940, ed. Fundação Alexandre de Gusmão, Brasília, 2012, p. 120; CANÇADO TRINDADE (A. A.), Repertório da prática diplomática brasileira do Direito Internacional Público, 1941-1960, ed. Fundação Alexandre de Gusmão, Brasília, 2012, pp. 86-90.

84 PEREIRA DE ARAUJO (J. H.), op. cit., p. 250.

${ }^{85}$ Segundo REUTER (P.), a exigência de promulgação está em via de desaparecimento (Droit international public, P.U.F., 4a ed., 1973, p. 39). Para um estudo dos países que adotaram o sistema da promulgação, v. PEREIRA DE ARAUJO (J. H.), op. cit., pp. 245-249.

86 Vide DAILLIER (P.), PELLET (A.), op. cit., p. 231 ; ROUSSEAU (C.), Droit international public, tomo I Introdução efontes, Sirey, Paris, 1971, p. 41.

${ }^{87}$ Nenhum decreto de promulgação de tratados foi adotado após 1947. O texto constitucional de 1958 adota implicitamente a mesma solução, eliminando definitivamente a exigência de promulgação. V. art. 55 da Constituição atual.

${ }^{88}$ Ministério das Relações Exteriores, Atos internacionais. Prática diplomática brasileira. Manual de procedimentos, Divisão de Assistência Consular, Divisão de Atos Internacionais, Brasília, 2008, p. 18.

${ }^{89}$ Artigo 84, IV da Constituição da República Federativa do Brasil de 1988.

${ }^{90} \operatorname{MESTRE}($ A.), op. cit., p. 257. 
publicação do decreto de promulgação ${ }^{91}$.

Em seguida, o decreto de promulgação será publicado no diário oficial, conforme determinado pela antiga tradição portuguesa ${ }^{92}$. É, precisamente, a partir da publicação do decreto de promulgação que o tratado se torna invocável internamente ${ }^{93}$. Trata-se de um meio juridicamente adequado a fim de tornar pública a celebração de um ato internacional, bem como determinar sua execução no direito interno ${ }^{94}$. Isso porque a publicação do decreto legislativo que aprova um ato internacional não é acompanhada de uma versão integral de seu texto. O Diário Oficial contém apenas uma menção ao ato internacional que acaba de ser aprovado. Esta prática foi empregada desde a adoção da primeira Constituição da República ${ }^{95}$. Assim, a importância do decreto de promulgação baseia-se na difusão do ato internacional perante a comunidade internacional.

Apesar deste aspecto positivo, a exigência de promulgação não apresenta outros benefícios. Pelo contrário, ela parece inadequada aos imperativos internacionais. Com efeito, a entrada em vigor no nível interno de um ato internacional não coincide com a entrada em vigor no nível internacional. Vimos que a entrada em vigor no nível interno começa a partir da publicação do decreto de promulgação. No que se refere à entrada em vigor internacional, esta é, frequentemente, acompanhada de certas formalidades destinadas a assegurar uma plena eficácia jurídica do tratado ${ }^{96}$. As formalidades aplicáveis às convenções multilaterais incluem o depósito de um determinado número de instrumentos que expressam o consentimento estatal junto ao depositário e o registo, por exemplo, perante a Secretaria das Nações Unidas, sendo esta última responsável por sua publicação ${ }^{97}$. A Convenção de Viena sobre o Direito dos

\footnotetext{
${ }^{91}$ Este último costuma conter um artigo 2, com o seguinte texto: "São sujeitos à aprovação do Congresso Nacional quaisquer atos que possam resultar em revisão do referido Tratado ou que acarretem encargos ou compromissos gravosos ao patrimônio nacional, nos termos do artigo 49, inciso I, da Constituição Federal". Tal referência no texto do decreto de promulgação representa uma simples reprodução do parágrafo único de qualquer decreto legislativo adotado a partir da discussão referente ao Acordo de Cooperação Científica e Tecnológica celebrado entre o Brasil e a Tchecoslováquia e aprovado através do decreto legislativo n.o 165, de 21 de Junho de 1991. Segundo MEDEIROS (A. P. C.), em 1991, esta fórmula foi transcrita no texto de 10 decretos legislativos (46,45\%); em 1992, em 37 decretos (84,09\%); e em 1993, em 6 decretos (75\%), op. cit., p. 426.

92 MEDEIROS (A. P. C.), op. cit., p. 470.

${ }^{93}$ DEBBASCH (C.), PONTIER (J.-M.), BOURDON (J.), RICCI (J.-C.), op. cit., p. 736. V. também PEREIRA DE ARAUJO (J. H.), op. cit., pp. 254-255.

94 PEREIRA DE ARAUJO (J. H.), op. cit., p. 251. Para mais detalhes referentes à exigência de promulgação e evolução dos textos constitucionais brasileiros, v. Ibid, pp. 249-254.

${ }_{95}$ Ibid, pp. 255-256.

${ }^{96}$ COMBACAU (J.), SUR (S.), op. cit., p. 136.

${ }^{77}$ Segundo DAILLIER (P.), PELLET (A.), esta limitação no número de ratificações necessárias é um avanço na técnica de celebração de tratados, pois facilita e agiliza sua passagem para direito positivo, op. cit., p.
} 
Tratados, de 1969, deixa uma grande liberdade aos Estados. Com efeito, a regra da entrada em vigor que ela adotou privilegia as modalidades e a data prevista em suas disposições ou acordada pelos Estados que participaram de sua negociação ou, em último caso, assim que o consentimento estatal em se vincular pelo tratado seja manifestado por todos os Estados que participaram na negociação ${ }^{98}$. O procedimento para a entrada em vigor aplicável às convenções multilaterais é geralmente a troca ou o depósito de um certo número de instrumentos de ratificação. A promulgação intervém apenas após a conclusão deste procedimento. Segue-se que um tratado já pode estar em vigor no nível internacional ou regional, mas ainda requerer um ato interno de promulgação para que se torne invocável no ordenamento jurídico brasileiro.

Esta dicotomia leva a pensar que a promulgação é uma espécie de ratificação interna, que não encontra seu lugar no direito internacional. A exigência de promulgação seria o resultado da adesão à doutrina dualista que manifestamente ignora as condições de entrada em vigor dos tratados internacionais ${ }^{99}$. Se a publicação constitui, para o tratado, uma condição de aplicabilidade da regra jurídica, a mesma observação vale, mutatis mutandis, para a promulgação. Assim, estas duas exigências não afetam a validade dos tratados internacionais. Somente a publicação seria amplamente suficiente, pois os atos internacionais são obrigatórios para o estado, sem qualquer modificação ${ }^{100}$. Ela seria útil para levar a norma que acaba de ser aprovada ao conhecimento dos sujeitos de direito interessados ${ }^{101}$. Com efeito, como afirma o jurista Paul de Visscher, a necessidade da publicação constitui o último freio que pode retardar a aplicabilidade dos tratados no ordenamento jurídico interno ${ }^{102}$.

É importante notar, no entanto, que a exigência de promulgação intervém apenas para os atos internacionais que não se enquadram na categoria de acordos executivos ${ }^{103}$. Com efeito, os acordos em forma simplificada não são promulgados por decretos. Eles são

162. O registro e a publicação dos tratados são regidos pelo artigo 80 da Convenção de Viena sobre o Direito dos Tratados de 1969. Ressalte-se que a sanção do tratado não registrado junto ao Secretário Geral é a simples "inexigibilidade" perante os órgãos da O.N.U., incluindo a C.I.J., em conformidade com o artigo 102, da Carta da ONU. A este respeito, v. DAILLIER (P.), PELLET (A.), op. cit., pp. 164-165.

98 Artigo 24 da Convenção de Viena sobre o direito dos tratados de 1969, realizada em Viena em 23 de maio de 1969, entrada em vigor em 27 de janeiro de 1980, Nações Unidas, Recueil des Traités, vol. 1155, p. 331.

99 DUPUY (P.-M), op. cit., p. 419

$100 \operatorname{MELLO}($ C. D. A.), op. cit., p. 241.

101 Para SCELLE (G.), nenhum ato de recepção ou de autoridade interna é necessário para conferir uma força obrigatória aos tratados. Não há sequer necessidade de promulgação, pois o ato de promulgação não tem outro significado jurídico que o de afirmar a validade do ato legislativo e fixar com precisão o momento de sua entrada em vigor", op. cit., p. 452.

102 VISSCHER (P. de), "Les tendances internationales des constitutions modernes", op. cit., p. 558.

103 Para mais detalhes, v. ROUSSEAU (C.), op. cit., pp. 70-73 e p. 90. 
simplesmente publicados no Diário Oficial pela Divisão de Atos Internacionais ("D.A.I.") após a autorização do Ministro das Relações Exteriores ${ }^{104}$. Eles entram em vigor a partir da expressão do consentimento estatal em vincular-se por meio de sua assinatura ${ }^{105}$, sendo que a publicação os torna devidamente invocáveis no ordenamento jurídico brasileiro.

Após avaliar a participação do poder executivo na incorporação do direito internacional, passa-se, agora, à análise da participação legislativa, a ser examinada em função do envio da norma ao Congresso Nacional pelo poder executivo.

\section{A intervenção limitada do poder legislativo}

É o poder executivo, na sua qualidade de mestre da política internacional, que dá o impulso para o procedimento de celebração de atos internacionais. Este somente submete ao Congresso Nacional, por meio de uma mensagem do Presidente, acompanhada de uma exposição de motivos, um ato internacional que acarrete compromissos gravosos ao patrimônio nacional. O procedimento perante o Congresso Nacional tem início com a apreciação da matéria pela Câmara dos Deputados (art. 64 da Constituição Brasileira).

O projeto é então distribuído às Comissões Permanentes, em conformidade com o regimento interno da Câmara ${ }^{106}$. Note-se que qualquer projeto de decreto legislativo que visa aprovar um ato internacional deverá passar pela Comissão de Relações Exteriores da Câmara dos Deputados. Após o recebimento do projeto, seu Presidente designa um relator escolhido dentre os membros da Comissão. O relator deverá emitir um relatório sobre o conteúdo do ato internacional em questão. Nesta ocasião, ele poderá recomendar para a Comissão, a aprovação, a rejeição total ou parcial, ou, ainda, a aposição de emendas ${ }^{107}$. Se o projeto for aprovado ${ }^{108}$, ele adquire o regime de emergência ${ }^{109}$.

Em seguida, o presidente poderá enviá-lo para as Comissões Permanentes competentes

\footnotetext{
104 MEDEIROS (A. P. C.), op. cit., p. 473; PEREIRA DE ARAUJO (J. H.), op. cit., p. 250. Ministério das Relações Exteriores, Atos internacionais. Prática diplomática brasileira. Manual de procedimentos, Divisão de Assistência Consular, Divisão de Atos Internacionais, Brasília, 2008, p. 18.

105 DAILLIER (P.), PELLET (A.), op. cit., p. 161. V. a este respeito WOJCIKIEWICZ ALMEIDA (P.), PEREIRA (M. F. L.), "As obrigações decorrentes da assinatura de um tratado internacional: noções preliminares", in Estudos de Direito Internacional, vol. XX, 8th Brazilian Congress on International Law, 2010, pp. 288-299.

${ }^{106}$ Artigo 137 e 22, e seguintes do Regimento Interno da Câmara dos Deputados (R.I.C.D.).

${ }^{107}$ A este respeito, v. segunda parte, título II, capítulo I, seção II, § 2, A).

${ }^{108}$ As decisões das Comissões serão adotadas por uma maioria de votos. A maioria absoluta dos membros deve estar presente, em conformidade com o artigo 56, § 2 do R.I.C.D.

${ }^{109}$ Artigo 151, I, j) e seguintes do R.I.C.D..
} 
na área ${ }^{110}$, antes de submetê-lo à Comissão de Constituição e Justiça. Esta última é sempre chamada a manifestar-se acerca dos aspectos técnicos do projeto, tais como a constitucionalidade, a legalidade, a técnica jurídica e legislativa ${ }^{111}$. É importante observar que cada projeto de decreto legislativo está limitado à análise substantiva de três Comissões Permanentes. Na sequência da aprovação da norma por estas últimas, o tema será incluído na ordem do dia e será votado perante a sessão plenária da Câmara dos Deputados. O plenário deve aprová-lo em primeira leitura, por maioria simples, na presença da maioria absoluta dos deputados para que ele seja posteriormente submetido ao Senado Federal ${ }^{112}$.

O projeto de decreto será, em seguida, distribuído ao Senado Federal para a apreciação das Comissões Permanentes e de seu plenário, em conformidade com o Regimento Interno ${ }^{113}$. Os projetos que visam incorporar um tratado internacional sempre são transmitidos à Comissão de Relações Exteriores e Defesa Nacional do Senado ${ }^{114}$. O Regimento Interno do Senado permite a introdução de emendas quando da adoção de um parecer da Comissão em espécie, que pode, portanto, aprová-lo ou rejeitá-lo. Depois de considerar os argumentos das autoridades dos partidos políticos, o Presidente do Senado pode conferir à Comissão acima mencionada a competência de apreciar definitivamente os projetos de decretos legislativos relativos aos atos internacionais ${ }^{115}$. Neste caso, esta será dotada de um poder final na aprovação de atos internacionais e do Mercosul| ${ }^{116}$. Suas decisões somente podem ser impugnadas por meio de um recurso assinado por um décimo dos senadores. As propostas apreciadas definitivamente pela Comissão de Relações Exteriores não estão sujeitas ao plenário do Senado Federal. Trata-se de uma maneira de acelerar o procedimento de conclusão dos atos internacionais. Uma segunda forma seria a inclusão na ordem do dia, pelo presidente, de um projeto de decreto quando este se referisse a um ato internacional que exigisse uma posição do Brasil no prazo máximo de dez dias. Esta possibilidade é indicada na seção 172, II, c) do Regimento Interno do Senado Federal.

Na ausência de ativação dos procedimentos acelerados acima, o projeto de norma seguirá as fases convencionais. Após a sua aprovação junto à Comissão de Relações Exteriores e

\footnotetext{
110 Artigo 17, II, a) e artigo 32 do R.I.C.D..

${ }^{111}$ Artigo 53, III e artigo 139, II, c) do R.I.C.D..

112 Artigo 183, R.I.C.D. e artigo 47 da Constituição da República Federativa do Brasil de 1988.

113 Artigo 5, III e IV da Resolução n. ${ }^{\circ}$ 01/07 e artigo 67 da Constituição da República Federativa do Brasil de 1988.

${ }^{114}$ Artigo 376 do Regimento interno do Senado Federal (R.I.S.F.).

115 Artigo 91, § $1^{\circ}$, I do R.I.S.F..

116 Essa competência também é conferida à Comissão de Relações Exteriores e Defesa Nacional e à Comissão de Constituição e Justiça da Câmara dos Deputados, nos termos do artigo 24, II do R.I.C.D..
} 
à Comissão de Constituição e Justiça, ele será incluído na ordem do dia do plenário. Se aprovado em primeira leitura, o texto do projeto de decreto legislativo será considerado como definitivamente aprovado pelo poder legislativo. Não restará mais do que a sua publicação pelo Presidente do Senado no Diário Oficial da União e do Congresso Nacional. A intervenção do poder legislativo não tem por efeito transformar o tratado em lei, ela serve unicamente para autorizar o Presidente da República a ratificar os tratados e torná-los exequíveis no direito interno pelo procedimento de promulgação ${ }^{117}$. A prática constitucional brasileira confirma a possibilidade conferida ao executivo de suspender o processo de aprovação de um ato internacional perante o Congresso Nacional, mesmo após o aval dado por uma de suas câmaras ${ }^{118}$. As razões pelas quais o executivo pode adotar esta posição dizem respeito, por um lado, à falta de interesse do executivo na aprovação de um tratado específico; e, por outro lado, ao risco de uma ausência de aprovação legislativa ${ }^{119}$.

O alcance do poder legislativo na aprovação dos atos internacionais tem sido objeto de numerosas controvérsias. Questionou-se qual era a extensão do poder do Congresso Nacional para a aprovação destes atos. É importante avaliar a possibilidade atribuída ao poder legislativo de se pronunciar através da aprovação parcial e de propor emendas em um texto internacional multilateral que poderão ser traduzidas pelo executivo como sendo reservas. Com efeito, o legislador brasileiro está limitado a apresentar propostas ao poder executivo. Essas propostas de emendas em sentido lato podem ser traduzidas pelo poder executivo como emendas em sentido estrito quando se trata de um tratado bilateral, ou como uma reserva de Estado no caso de um tratado multilateral.

A possibilidade conferida ao legislativo de propor emendas que assumirão a forma de uma reserva de Estado ou de uma declaração interpretativa ${ }^{120}$ em um tratado internacional

\footnotetext{
${ }^{117}$ A aprovação por decreto legislativo inclui apenas, para o presidente, uma autorização para ratificar e promulgar a seu critério, como testemunha a possibilidade de denúncia por ato unilateral do Chefe de Estado. A este respeito, v. MESTRE (A.), op. cit., p. 78.

118 Para mais detalhes sobre a possibilidade concedida ao executivo de suspender a aprovação legislativa perante o Congresso Nacional, v. CANÇADO TRINDADE (A. A.), Repertório da prática diplomática brasileira do Direito Internacional Público, 1899-1918, ed. Fundação Alexandre de Gusmão, Brasília, 2012, pp. 168172.

119 MAIA (R. M.), A política externa brasileira e o Congresso Nacional (1988-2003), dissertação de mestrado, UnB, Brasília, 2005, p. 59.

120 De acordo com a Comissão de Direito Internacional, a expressão 'declaração interpretativa' é tomada no sentido de uma declaração unilateral, qualquer que seja sua redação ou designação, feita por um Estado ou por uma organização internacional, pela qual esse Estado ou essa organização visa especificar ou esclarecer o sentido e o alcance que o declarante atribui a um tratado ou a algumas de suas disposições, in "Le droit et la pratique concernant les réserves aux traités" (A/CN.4/L.575, Annuaire de la
} 
dividiu a doutrina brasileira, bem como os poderes executivo e legislativo. Surgiram duas correntes opostas: uma autorizando a aprovação legislativa parcial de um tratado internacional, através da introdução de emendas; e outra proibindo qualquer alteração de um tratado assinado pelo executivo, reconhecendo-lhe a competência exclusiva para emitir reservas ${ }^{121}$. As origens do primeiro discurso, que visam aumentar as prerrogativas do Congresso Nacional, remontam à entrada em vigor da Constituição de 1891, seguindo o exemplo norte-americano. De acordo com os defensores desta corrente, limitar a atividade do Congresso a simplesmente aprovar ou rejeitar tratados internacionais imporia obstáculos à política internacional, pois o conteúdo de um tratado pode ser válido, apesar de alguns detalhes suscetíveis de modificação $0^{122}$.

Para a segunda corrente, o Congresso estaria limitado à aprovação ou à rejeição total dos tratados internacionais ${ }^{123}$. A autorização conferida ao Congresso para propor uma emenda a um tratado significaria rejeição per totum, pois o poder legislativo é competente para decidir definitivamente sobre os tratados internacionais e não aprová-los parcialmente ou sugerir modificações ${ }^{124}$. Tal interpretação significaria afirmar que sua competência não seria definitiva, como prevê o texto constitucional. De acordo com os defensores desta segunda corrente, qualquer sugestão de modificação exigiria uma renegociação do tratado por parte do governo ${ }^{125}$.

Esta discussão favoreceu uma tomada de posição pelo executivo para aceitar a

Commission du droit international, 1999, vol. I, Relatórios analíticos das assembleias da quinquagésima primeira sessão, 2597e assembleia, p. 226.

${ }^{121}$ Os autores que têm seguido esta tendência foram reagrupados por MEDEIROS (A. P. C.), O poder legislativo..., op. cit., p. 97.

122 LEAL (A.), Teoria e prática da Constituição federal brasileira, vol. I, Rio de Janeiro, p. 4 e seguintes. Para uma posição intermediária, v. MAXIMILIANO (C.), Comentários à Constituição Brasileira de 1946, n.․ 353, vol. II, pp. 146-147.

123 Essa abordagem tem sido seguida por muitos comentaristas do texto constitucional, tais como: MILTON (A.), A Constituição do Brasil, notícia histórica, texto e comentário, Imprensa nacional, Rio de Janeiro, 1898, p. 142; BEVILAQUA (C.), Direito Publico Internacional, Freitas Bastos, 2a ed., tomo II, Rio de Janeiro, 1939, p. 18; DEODATO (A.), "Pode o Congresso apresentar emendar aos Acordos Internacionais?", Revista da Faculdade de Direito da Universidade de Minas Gerais, Belo Horizonte, outubro, 1953, p. 140; ARAUJO (J. H. P.), op. cit., p. 195. Referente à impossibilidade de uma aprovação parcial da parte do Congresso Nacional e a limitação de seus poderes, v. CANÇADO TRINDADE (A. A.), Repertório da prática diplomática brasileira do Direito Internacional Público, 1919-1940, ed. Fundação Alexandre de Gusmão, Brasília, 2012, pp. 109-111; CANÇADO TRINDADE (A. A.), Repertório da prática diplomática brasileira do Direito Internacional Público, 1941-1960, ed. Fundação Alexandre de Gusmão, Brasília, 2012, pp. 86-90.

${ }^{124}$ BARBALHO (J.), Constituição federal brasileira, comentários, 2a ed., Rio de Janeiro, 1924, p. 150.

125 MIRANDA (P.), Comentários à constituição de 1967, tomo III, Revista dos Tribunais, 2a ed., São Paulo, 1967, p. 103 e pp. 106-107. 
aprovação parcial com a proposta de emendas pelo poder legislativo ${ }^{126}$. O Ministério das Relações Exteriores não ratificou a tese de que a aprovação legislativa deve ser obrigatoriamente total ${ }^{127}$. O Congresso Nacional, portanto, é livre para aprovar, total ou parcialmente, com sugestões de emendas em sentido amplo. Estas poderão ser propostas sob a forma de emendas do executivo para outros Estados contratantes e aceitas por eles (o que parece muito difícil na prática no que se refere aos tratados multilaterais, pois isso exigiria a renegociação do mesmo); ou ser traduzidas como reservas pelo executivo quando da ratificação de um tratado multilateral, caso este o permitisse expressamente ou caso elas não fossem incompatíveis com o objeto e a finalidade do tratado.

O Congresso Nacional já tomou posição em relação ao escopo do artigo 49 da Constituição Brasileira, que the confere o poder de aprovar os tratados internacionais que acarretem encargos ou compromissos gravosos ao patrimônio nacional. Desde a entrada em vigor da Constituição de 1946, o poder legislativo brasileiro habitualmente aprova atos internacionais propondo reservas ou emendas ${ }^{128}$. A extensão de seus poderes é confirmada pelo Regimento da Câmara dos Deputados e do Senado federal ${ }^{129}$. A posição do Congresso Nacional também encontra fundamento nos pareceres emitidos pelas Comissões de suas duas câmaras responsáveis pela análise dos tratados internacionais que lhe foram submetidos ${ }^{130}$.

\footnotetext{
126 Diversos conselheiros jurídicos do Ministério das Relações Exteriores do Brasil se pronunciaram sobre a possibilidade de aprovação parcial pelo poder legislativo. Vide, nesse sentido, VALLADAO (H.), "Conceito moderno de ratificação dos tratados e convenções, democrático, originário do Direito Internacional americano", in MEDEIROS (A. P. C.) (Org.), Pareceres dos consultores jurídicos do Itamaraty, vol. VI, 19611971, Senado Federal, Brasília, 2008, pp. 80-94; PIRES (N. S. V.), A atuação do Congresso Nacional na celebração de tratados internacionais, legislatura 1999-2002, Universidade de Brasília, Curso de Especialização em Gestão Legislativa, Brasília, 2003, p. 20; RANGEL (V. M.), "Emendas dos tratados internacionais", in MEDEIROS (A. P. C.) (Org.), Pareceres dos consultores jurídicos do Itamaraty, vol. IX, 1990-1999, Senado Federal, Brasília, 2008, p. 88; RANGEL (V. M.), "Questão de saber se emenda de tratado bilateral implica necessariamente rejeição. Precedente invocado", in MEDEIROS (A. P. C.) (Org.), Pareceres dos consultores jurídicos do Itamaraty, vol. IX, 1990-1999, Senado Federal, Brasília, 2008, pp. 98-99; RANGEL (V. M.), "Emendas dos tratados internacionais", op. cit., p. 87; RANGEL (V. M.), "Questão de saber se emenda de tratado bilateral implica necessariamente rejeição (...)", op. cit., pp. 98-99; REZEK (F.), Direito Internacional Publico, Saraiva, 11a ed., São Paulo, 2008, p. 68.

127 REZEK (F.), op. cit., p. 68.

128 MEDEIROS (A. P. C.), op. cit., p. 442.

129 V. a este respeito os artigos 118 a 125 do Regimento Interno da Câmara dos Deputados (R.I.C.D.) e artigo 376, III do Regimento Interno do Senado Federal (R.I.S.F.). O R.I.C.D., no seu capítulo V, determina o procedimento aplicável para inserir emendas e seus diferentes tipos permitidos nas propostas de atos legislativos.

130 V. PIRES (N. S. V.), op. cit., pp. 19-20. Faz-se habitualmente referência ao parecer de VALLADÃO (H.), ex-conselheiro jurídico do Ministério das Relações Exteriores, que argumentou que o Congresso estava autorizado a propor emendas no acordo sobre comércio e pagamentos entre Brasil e Tchecoslováquia. Vide Consulta n.o 7, de 1993, que é particularmente ilustrativa a este respeito. Trata-se de uma solicitação feita pela Presidência da Câmara dos Deputados acerca das reservas sugeridas aos artigos 25 e
} 
Um exemplo mais recente de aprovação parcial pelo Congresso Nacional refere-se ao texto da Convenção de Viena sobre o Direito dos Tratados de 1969. Como visto anteriormente, o decreto legislativo n.o 496/2009, que aprovou parcialmente a Convenção, somente foi adotado em 17 de julho de $2009^{131}$. Seu primeiro parágrafo centra-se nas as propostas de reservas formuladas pelo Congresso e menciona expressamente dois artigos da Convenção: por um lado, o artigo 25 referente à aplicação a título provisório de um tratado ou de uma parte de um tratado até à sua entrada em vigor ${ }^{132}$; e, por outro lado, o artigo 66 relativo ao procedimento de solução de controvérsias judicial, de arbitragem e de conciliação ${ }^{133}$. O decreto de promulgação da Convenção de Viena sobre o Direito dos Tratados de 1969, adotado pelo executivo em 14 de dezembro de 2009, confirma as reservas aos artigos supramencionados, em conformidade com as propostas do Congresso Nacional, em seu decreto de 17 de julho de $2009^{134}$.

Assim, vê-se que a tese de uma limitação dos poderes do Congresso Nacional para aprovação ou rejeição total está desatualizada ${ }^{135}$. A extensão dos poderes legislativos tem sido reconhecida tanto pelo poder executivo quanto pelo legislativo. Na prática, este último exerce também suas competências por meio da aprovação parcial, podendo propor emendas em sentido amplo ${ }^{136}$. No entanto, poderíamos questionar a utilidade do poder de aprovar

66 da Convenção de Viena sobre o Direito dos Tratados de 1969 pelas Comissões de Relações Exteriores, de Constituição, de Justiça e de Redação.

${ }^{131} \mathrm{~V}$. projeto de decreto legislativo apresentado pela Comissão de Relações Exteriores, que aprovou com reservas a Convenção de Viena sobre o Direito dos Tratados de 1969, em 02 de dezembro de 1992, nos termos do parecer feito deputado Antônio Carlos Mendes Thame, que considerava os artigos 25 e 66 como incompatíveis com a Constituição Brasileira.

132 V. artigo 25 da Convenção de Viena Sobre o Direito dos Tratados de 1969.

${ }^{133}$ V. artigo 66 da Convenção de Viena sobre o Direito dos Tratados de 1969.

134 Decreto n. 7.030, de 14 de dezembro de 2009, publicado no Diário Oficial da União n.o 239, seção I, em 15 de dezembro de 2009.

135 É raro na história constitucional brasileira que um decreto legislativo venha a defender a rejeição de um tratado internacional. Um exemplo é o tratado assinado entre o Brasil e a Argentina em 25 de janeiro de 1890, referente à fronteira das Missões, que foi rejeitado pelo plenário do Congresso em 18 de agosto de 1891 (Representação Brasileira no Parlamento do Mercosul, Fundamentos da integração regional: o Mercosul, Congresso Nacional, pp. 194-195).

136 PIRES (N.S.V.) avaliou o número de acordos internacionais que receberam emendas pelo Congresso Nacional durante a sessão legislativa de 1999. Ela concluiu que 24 mensagens do poder executivo sobre os tratados internacionais foram transformados em projeto de decreto legislativo. Desses projetos, 16 deles tornaram-se, realmente, decretos legislativos, dos quais 12 foram alterados pelas Comissões ou pelo plenário da Câmara dos Deputados, apenas um recebeu uma segunda emenda pelo Senado Federal (op. cit., p. 21). Durante a legislatura de 1999-2002, 137 mensagens do poder executivo sobre os tratados internacionais foram transformadas em projeto de decreto legislativo pela Comissão de Relações Exteriores e Defesa Nacional da Câmara dos Deputados, dos quais 31 reberam alterações, reservas ou cláusulas interpretativas. Ao final da legislatura analizada, ainda restavam 64 projetos de decreto 
parcialmente se, em substância, o parecer do Congresso não obriga o executivo a tomar uma posição de acordo com suas recomendações. Nesta linha, o exercício do poder de aprovação sempre permanece dependente da submissão, pelo executivo, de um ato internacional ao Congresso Nacional, caso este acarrete encargos ou compromissos gravosos ao patrimônio nacional. Estas são as razões pelas quais seria importante prever outros meios para ampliar este poder.

\section{CONCLUSÃO}

O processo brasileiro de conclusão de tratados foi marcado, inicialmente, por uma competência partilhada, como previsto na Constituição Belga de 1831, que serviu de modelo para o Brasil e outros países. Se a Constituição Política do Império do Brasil, de 25 de março de 1824, optou pela submissão ao poder legislativo de alguns tratados considerados como mais importantes, as revisões constitucionais subsequentes objetivaram assegurar uma participação obrigatória do poder legislativo no processo de conclusão de tratados. Os textos constitucionais adotados a partir de 1891 foram nessa mesma linha.

As regras relativas ao poder de celebrar tratados da Constituição de 1988 rompem com a lógica das constituições anteriores, que estavam baseadas na fórmula de franco-belga de repartição de competências. O texto atual confere uma ampla margem de manobra ao poder executivo que pode decidir quais tratados acarretam encargos ao patrimônio nacional e devem, portanto, ser submetidos ao Congresso Nacional. A interpretação das disposições constitucionais pode levar a um uso indevido das regras relativas à celebração de atos internacionais no Brasil. Conforme visto, o objetivo implícito da fórmula atual era o de fortalecer o poder executivo no processo de conclusão de tratados, em continuidade com os regimes militares, privilegiando, ao mesmo tempo, sua eficácia. Isto poderia subentender uma intenção deliberada de evitar a intervenção do poder legislativo sem violar abertamente os imperativos democráticos.

Em todo caso, pode-se pensar que a Constituição de 1988 não dividiu adequadamente as competências executivas e legislativas ${ }^{137}$. Esta situação favoreceu o desenvolvimento da prática dos acordos executivos, transposta para a realidade brasileira por meio de uma discussão doutrinária realizada sob a égide da Constituição de 1946. Atualmente, a prática

legislativo junto à Câmara ou ao SENADO, o que leva a afirmar que alguns deles ainda poderiam ser alterados (Ibid, p. 40).

${ }^{137}$ Entrevista com Marcelo Zero, técnico da Câmara dos Deputados, em 29 de outubro de 2009. 
diplomática brasileira aceita a celebração de tratados em forma simplificada, de acordo com determinados critérios. No entanto, a imprecisão desses critérios gera "uma prática constitucional que tende a reestabelecer em proveito do Presidente este jus repraesentationis omnimodae que conhecia o antigo direito internacional" ${ }^{138}$. O aumento do número de acordos executivos constitui a prova. O próprio propósito destes acordos tende a estender-se às áreas de competência do poder legislativo, em violação das normas constitucionais. Os acordos executivos, portanto, podem ser empregados para evitar a participação do poder legislativo no procedimento de conclusão de atos internacionais.

A partir das regras constitucionais que regem o treaty-making power o presente artigo avaliou o processo de incorporação dos tratados internacionais no Brasil, que é marcado por um desequilíbrio entre os poderes executivo e legislativo, típico de um país sob um regime presidencial. É o poder executivo que domina todo o processo de conclusão de atos internacionais. Tal controle ocorre em diferentes fases, com pouca interferência do poder legislativo. Após assinar um ato internacional, o executivo decide sobre seu envio ao Congresso Nacional para aprovação. Esta escolha é feita de acordo com regras constitucionais genéricas e imprecisas da Constituição de 1988. Será necessário avaliar o conteúdo e a natureza do ato internacional a ser incorporado para saber se este acarreta encargos ao patrimônio nacional.

Se a ação do poder do executivo é discricionária e não arbitrária, ela não é imune a críticas. O exemplo levantado sobre a incorporação da Convenção de Viena sobre o Direito dos Tratados de 1969 constitui a prova. Neste caso particular, tanto o poder executivo, quanto o poder legislativo contribuíram para a lentidão do procedimento de incorporação. Tal exemplo demonstra que um texto internacional pode esperar 23 anos até que a administração decida enviá-lo ao Congresso para aprovação. A falta de vontade política pode, portanto, prejudicar, ou até mesmo impedir a entrada em vigor dos atos internacionais. Pode eventualmente levar a excluir a participação do Congresso Nacional, quando este deveria se pronunciar. Esta mesma situação pode ocorrer quando o poder executivo não adota o decreto de promulgação de um tratado internacional. Mesmo que a promulgação intervenha após a aprovação legislativa, o poder executivo não é obrigado a fazê-lo. Portanto, é possível ativar desnecessariamente a máquina do processo legislativo mesmo que as razões de conveniência política conduzam o poder executivo a não mais se obrigar na esfera internacional.

A exigência de promulgação não está prevista no texto constitucional, mas resulta de

138 Tradução livre do autor. VISSCHER (P. de), op. cit., p. 540. 
uma prática diplomática brasileira que data da época do Império. Essa prática já é incompatível com as exigências da sociedade internacional, favorecendo uma defasagem entre a entrada em vigor no nível internacional e a entrada em vigor no nível brasileiro. A consequência é uma insegurança jurídica que poderia levar a questionar os compromissos assumidos pelo Brasil no âmbito internacional.

A avaliação do processo de incorporação junto ao Congresso Nacional seria incompleta sem uma análise do escopo de seu poder de aprovação dos atos internacionais. Este poder foi contestado pelo Congresso Nacional, que insistiu em ir além da aprovação ou da rejeição total. Para o Congresso, seria necessário garantir o respeito de suas prerrogativas através de uma aprovação parcial com a proposta de emendas para o poder executivo, pois qui potest maius, potest et minus. Este último, por meio dos pareceres emitidos pelos conselheiros jurídicos do Itamaraty, não vê nenhum obstáculo à aprovação parcial, mesmo que as consequências desta aprovação, frequentemente, não sejam claras. Entretanto, parece que a oportunidade de propor emendas ao poder executivo não atingirá a finalidade desejada sem que se considere outros meios capazes de ampliar os poderes do Congresso Nacional.

Existem alternativas previstas pelos Regimentos Internos da Câmara dos Deputados e do Senado, porém não são frequentemente utilizadas por seus membros. A insuficiência dos mecanismos atuais poderia ser amenizada por meio da criação de novos mecanismos que serviriam para esclarecer as regras existentes. Apesar da proposição de projetos no sentido de regulamentar a apreciação dos atos internacionais pelo Congresso Nacional e de alterar o texto constitucional a fim de prever prazos para a incorporação de atos internacionais pelo poder executivo, tais iniciativas foram arquivadas em 1999 e 2011, respectivamente.

\section{REFERÊNCIAS BIBLIOGRÁFICAS}

\section{Livros e capítulos}

ARAÚJO, J. H. P., A processualística dos atos internacionais, Ministério das Relações Exteriores, Rio de Janeiro, 1958.

BALEEIRO, A., Constituições brasileiras, vol. 2 - 1891, Senado Federal, Ministério da Ciência e da Tecnologia, Centro de Estudos Estratégicos, 2001.

BALEEIRO, A., SOBRINHO, B. L., Constituições brasileiras, vol. 5 - 1946, Senado Federal, Ministério da Ciência e da Tecnologia, Centro de Estudos Estratégicos, 2001.

BARBALHO, J., Constituição federal brasileira, comentários, 2a ed., Rio de Janeiro, 1924. 
BASTOS, C. R. V., Comentários à Constituição do Brasil, Saraiva, 3a ed., vol. 4, t.1, São Paulo, 2002.

BERRANGER, T. Constitutions nationales et construction communautaire, L.G.D.J., Paris, 1995.

BEVILAQUA, C., Direito Público Internacional, Freitas Bastos, 2a ed., tomo II, Rio de Janeiro, 1939.

BUENO, J. A. P., Direito Público Brasileiro e Análise da Constituição do Império, Senado Federal, Brasília, 1978.

CANÇADO TRINDADE, A. A. Tratado de Direito Internacional dos Direitos Humanos, Sérgio Antônio Fabris Editor, 2a ed., 2003.

CARREAU, D. Droit international, Pedone, 9a ed., Paris, 2007.

CAVALCANTI, J. B. U., Constituição Federal Brasileira (1891), coleção História Constitucional Brasileira, Senado Federal, Brasília, 2002.

CAVALCANTI, T. B., BRITO, L. N., BALEEIRO, A., Constituições brasileiras, vol. 6 - 1967, Senado Federal, Ministério da Ciência e da Tecnologia, Centro de Estudos Estratégicos, 2001.

CHALTIEL, F. La souveraineté de l'État et l'Union européenne, l'exemple français, Recherches sur la souveraineté de l'État membre, L.G.D.J., 2000.

DAILLER, P. FORTEAU, M., PELLET, A. Droit International Public, LGDJ, 8a ed., Paris, 2009.

DAILLER, P. PELLET, A. Droit International Public, L.G.D.J., 7a ed., Paris, 2002.

DEBBASCH, C., PONTIER, J.-M., BOURDON, J., RICCl, J.-C., Droit constitutionnel et institutions politiques, Economica, 4a ed., Paris, 2001.

DUPUY, P.-M., Droit international public, Dalloz, 8a ed., Paris, 2006.

FERREIRA FILHO, M. G., Comentários à Constituição Brasileira de 1988, vol. II, Saraiva, São Paulo, 1992.

Comentários à Constituição Brasileira, Saraiva, 6ạ ed., São Paulo, 1986.

FRANCO, A. A. M., Estudos de Direito Constitucional, Forense, Rio de Janeiro, 1957.

LAMOUNIER, B., "A feitura da nova constituição: um reexame da cultura política brasileira" In.: Lamounier, B. (Org.), De Geisel a Collor: o balanço da transição, ed. Sumaré, São Paulo, 1990.

LEAL, A. A., História Constitucional do Brasil, coleção História Constitucional Brasileira, Senado Federal, Brasília, 2002.

MAIA, R. M., A política externa brasileira e o Congresso Nacional (1988-2003), dissertação de mestrado, UnB, Brasília, 2005. 
MALBERG, R. C., Contribution à la théorie générale de l'État, Sirey, Paris, 1920, C.N.R.S., 1962.

MARTINEZ-LARA, J. Building Democracy in Brazil: Politics of Constitutional Change, 1985-1995, St. Martin's Press, New York, 1996.

MASCLET, J.-C., MAUS, D. (org.), Les constitutions nationales à l'épreuve de l'Europe, Centre de recherches de droit constitutionnel - Paris 1, La Documentation française, 1993.

MAXIMILIANO, C., Comentários à Constituição Brasileira de 1946, n.o 353, vol. II.

MEDEIROS, A. P. C. O poder de celebrar tratados, Sergio Antonio Fabris, Porto Alegre, 1995.

"Vigência no ordenamento jurídico brasileiro das normas emanadas dos órgãos do Mercosul com capacidade decisória", In.: Basso, M., Prado, M. A., Zaitz, D., Direito do Comércio Internacional, Juruá, Curitiba, 2008.

O Poder Legislativo e os Tratados Internacionais, Instituto dos Advogados do Rio Grande do Sul/L\&PM, Porto Alegre, 1983.

O Poder Moderador na República Presidencial, coleção História Constitucional Brasileira, Senado Federal, Brasília, 2004.

MELLO, C. A. Curso de Direito Internacional Público, Renovar, 15a ed., 2004.

MILTON, A., A Constituição do Brasil, notícia histórica, texto e comentário, Imprensa nacional, Rio de Janeiro, 1898.

MIRANDA, P., Comentários à Constituição de 1967, tomo III, Revista dos Tribunais, São Paulo, 1967.

NOGUEIRA, O., Constituições brasileiras, vol. 1 - 1824, Senado Federal, Ministério da Ciência e da Tecnologia, Centro de Estudos Estratégicos, 2001.

PEREIRA DE ARAUJO, J. H. A processualística dos Atos Internacionais, Ministério de Relações Exteriores, Rio de Janeiro, 1958.

PEROTTI, A. Habilitación constitucional para la integración comunitaria, tomo I, Konrad Adenauer Stiftung, Montevidéu, 2004.

Habilitación constitucional para la integración comunitaria, tomo II, Konrad Adenauer Stiftung, Montevidéu, 2004.

PIRES, N. S. V., A atuação do Congresso Nacional na celebração de tratados internacionais, legislatura 1999-2002, Universidade de Brasília, Curso de Especialização em Gestão Legislativa, Brasília, 2003.

POLETTI, R., Constituições brasileiras, vol. 3 - 1934, Senado Federal, Ministério da Ciência e da Tecnologia, Centro de Estudos Estratégicos, 2001.

PORTO, W. C., Constituições brasileiras, vol. 4 - 1937, Senado Federal, Ministério da Ciência e da Tecnologia, Centro de Estudos Estratégicos, 2001.

REALE, M., Figuras da inteligência brasileira, Siciliano, 2a ed., 1994. 
RIDEAU, J. Droit institutionnel de I'Union et des Communautés européennes, L.G.D.J., 4a ed., Paris, 2002.

REUTER, P., Droit international public, P.U.F., 4a ed., 1973.

REZEK, F., Direito Internacional Publico, Saraiva, 11a ed., São Paulo, 2008.

ROUSSEAU, C., Droit international public, Dalloz, 11a ed., Paris, 1987.

SARLET, I. A eficácia dos direitos fundamentais: uma teoria geral dos direitos fundamentais na perspectiva constitucional, Livraria do advogado, 10aㅡ ed., 2011.

SILVA, J. A., Curso de direito constitucional positivo, Malheiros, 25a ed., São Paulo, 2005.

VALLADAO, H. V., "Conceito moderno de ratificação dos tratados e convenções, democrático, originário do Direito Internacional americano", In.: Medeiros, A. P. C. (Org.), Pareceres dos consultores jurídicos do Itamaraty, vol. VI, 1961-1971, Senado Federal, Brasília, 2008.

VATTEL, E., Le droit des gens ou principes de la loi naturelle appliqués à la conduite et aux affaires des nations et des souverains, v. 3, The Carnegie Institution, Washington, 1916.

VEDEL, G., Manuel élémentaire de droit constitutionnel, Librairie Du Recueil Sirey, Paris.

VIRALLY, M., "Unilateral acts of international organizations", In.: Bedjaoui, M. Org.), International law: achievements and prospects, ed. Martinus Nijhoff, Dordrecht, 1991.

"Sur un pont-aux-ânes: les rapports entre droit international et droits internes", Mélanges H. Rolin, Paris, Pedone, 1964.

VISSCHER, P. de, "L'adaptation de la Constitution belge aux réalités internationales", Atos do colóquio de 6 e 7 de maio de 1965, Editions de l'institut de sociologie, Bruxelas.

WHEATON, H., Eléments du droit international, A. Durand, Paris, 1848, t. 1.

\section{Artigos}

BANDEIRA GALINDO, G. R. “O §3 do art. 5o da Constituição Federal: um retrocesso para a proteção internacional dos direitos humanos no Brasil". Revista do Instituto Brasileiro de Direitos Humanos, vol. 6, n. 6, 2005.

BRAGA, S. S., "A constituinte de 1946 e a nova ordem econômica e social do pós-segunda guerra mundial", Revista de Sociologia e Política, Curitiba, n.o 6 e 7, 1996.

CÂMARA, J. S., "A conclusão dos tratados internacionais e o direito constitucional brasileiro", Boletim da Sociedade Brasileira de Direito Internacional, Brasília, ns. 69/71, 1987-1989.

DEODATO, A., "Pode o Congresso apresentar emendar aos Acordos Internacionais?", Revista da Faculdade de Direito da Universidade de Minas Gerais, Belo Horizonte, outubro, 1953. 
FERREIRA, M. C. "Os processos constituintes de 1946 e 1988 e a definição do papel do Congresso Nacional na política externa brasileira", Revista brasileira de política internacional, n. o 53 (2), 2010.

ISAAC, G. "Primauté du droit communautaire", Rép. Communautaire Dalloz, outubro de 1997.

MEHDI, R. "Ordre juridique communautaire - primauté du droit communautaire", Jurisclasseur Europe Traité, fasc. 196, 3, 2006.

RIDEAU, J. "Constitution et droit international dans les États membres des Communautés européennes", R.F.D.C., 1990.

RODAS, J. G., "A publicidade dos tratados internacionais", Revista dos Tribunais, São Paulo, 1980.

WOJCIKIEWICZ ALMEIDA, P., PEREIRA, M. F. L., "As obrigações decorrentes da assinatura de um tratado internacional: noções preliminares", in Estudos de Direito Internacional, vol. XX, Anais do 8o Congresso Brasileiro de Direito Internacional, ed. Juruá, Curitiba, 2010.

"Revisitando os efeitos da assinatura de um tratado internacional: da obrigação de boa-fé à sujeição internacional do Estado", Revista DIREITO GV, v. 9, n. 1, jan-jun 2013.

KELSEN (H.), "Les rapports de système entre le droit interne et le droit international public", R.C.A.D.I., 1926-IV, pp. 227-331

MAHAIM (E.), "L'organisation permanente du travail”, R.C.A.D.I., 1924, III, vol. 4, pp. 65-223.

MAUPAIN (F.), “L'OIT, la justice sociale et la mondialisation", R.C.A.D.I., 1999, vol. 278, pp. 201396.

MESTRE (A.), "Les traités et le droit interne”, R.C.A.D.I., 1931-IV, pp. 233-306.

MIRKINE-GUETZÉVITCH (B.), « Droit international et droit constitutionnel », R.C.A.D.I., 1931-IV, pp. 307-465.

MOSLER, H., "L'application du droit international public par les tribunaux nationaux", R.C.A.D.I., 1957-I, n. ㅇ 91, pp. 625-709.

SCELLE (G.), "Règles générales du droit de la paix", R.C.A.D.I., 1933, t. 46, pp. 327-703.

TRIEPEL (H.), "Les rapports entre le droit interne et le droit international", R.C.A.D.I., 1923-I, pp. 77-118.

VISSCHER (P. de), "Les tendances internationales des constitutions modernes", R.C.A.D.I., 1952I, pp. 511-578.

WOLF (F.), "L'interdépendance des Conventions internationales au travail", R.C.A.D.I., 1967, II, vol. 121, pp. 113-219. 
RANGEL (V. M.), "Emendas dos tratados internacionais", In.: MEdeIROS (A. P. C.) (Org.), Pareceres dos consultores jurídicos do Itamaraty, vol. IX, 1990-1999, Senado Federal, Brasília, 2008.

"Questão de saber se emenda de tratado bilateral implica necessariamente rejeição. Precedente invocado", In.: MEDEIROS (A. P. C.) (Org.), Pareceres dos consultores jurídicos do Itamaraty, vol. IX, 1990-1999, Senado Federal, Brasília, 2008, pp. 98-99

VALLADÃO (H.), «Conceito moderno de ratificação dos tratados e convenções, democrático, originário do Direito Internacional americano », In.: MEDEIROS (A. P. C.) (dir.), Pareceres dos consultores jurídicos do Itamaraty, vol. VI (1961-1971), éd. Sénat fédéral, Brasília, 2002, pp. 244286.

\section{Repertório da Prática Diplomática Brasileira}

CANÇADO TRINDADE, A. A., Repertório da prática diplomática brasileira do Direito Internacional Público, 1889-1898, éd. Fundação Alexandre de Gusmão, Brasília, 2012, 302 p.

Repertório da prática diplomática brasileira do Direito Internacional Público, 1899-1918, éd. Fundação Alexandre de Gusmão, Brasília, 2012, 587 p.

Repertório da prática diplomática brasileira do Direito Internacional Público, 1919-1940, éd. Fundação Alexandre de Gusmão, Brasília, 2012, 388 p.

Repertório da prática diplomática brasileira do Direito Internacional Público, 1941-1960, éd. Fundação Alexandre de Gusmão, Brasília, 2012, 444 p.

Repertório da prática diplomática brasileira do Direito Internacional Público, 1961-1981, éd. Fundação Alexandre de Gusmão, Brasília, 2012, 424 p.

Trabalho enviado em 03 de janeiro de 2018.

Aceito em 11 de janeiro de 2018. 